\title{
Southern Ocean temperature records and ice-sheet models demonstrate rapid Antarctic ice sheet retreat under low atmospheric $\mathrm{CO}_{2}$ during Marine Isotope Stage 31 .
}

*Beltran Catherine ${ }^{1}$, Golledge Nicholas R. ${ }^{2,3}$, Ohneiser Christian ${ }^{4}$, Kowalewski

Douglas E. ${ }^{5}$, Sicre Marie-Alexandrine ${ }^{6}$, Hageman Kimberly J. ${ }^{7}$, Smith Robert ${ }^{1}$,

Wilson Gary S. ${ }^{1}$, Mainié François ${ }^{6}$.

1. Department of Marine Science, University of Otago, PO Box 56, Dunedin 9054, New Zealand catherine.beltran@otago.ac.nz

2. Antarctic Research Centre, Victoria University of Wellington, Wellington 6140, New Zealand

3. GNS Science, Avalon, Lower Hutt 5011, New Zealand

4. Department of Geology, University of Otago, PO Box 56, Dunedin 9054, New Zealand

5. Department of Earth, Environment, and Physics, Worcester State University, Worcester, Massachusetts 01602, USA

6. Sorbonne Universités (UPMC, Univ. Paris 06)-CNRS-IRD-MNHN, LOCEAN Laboratory, 4 Place Jussieu, F-75005 Paris, France.

7. Department of Chemistry, University of Otago, PO Box 56, Dunedin 9054, New Zealand

\section{Highlights}

- We quantify precisely the magnitude of ocean warming using the first ever Southern Ocean molecular paleo-temperature reconstructions during the warm Marine Isotope Stage 31 (MIS31- 1.085 and 1.055 million years ago).

- Our data show a sustained surface Southern Ocean warming and a collapse of the Antarctic and sub Antarctic ocean fronts during that warm period and under low atmospheric $\mathrm{CO}_{2}$ concentrations.

- We use sea surface temperature reconstructions to test the scenarios for the AIS retreat during MIS31 using coupled ice-sheet/ice-shelf model.

- We propose a two-step model for deglaciating West Antarctica which involves mild ocean warming (a new temperature threshold) which forces ice margin retreat followed by rapid ocean warming as the ice sheet retreats.

- Our work shows that the Paris Agreement target temperature of $1.5^{\circ} \mathrm{C}$ is sufficient to drive runaway retreat of the West Antarctic Ice Sheet. We derive this conclusion from the robust, ocean temperature proxy record and ice sheet simulation. 


\section{Abstract}

Over the last 5 million years, the Earth's climate has oscillated between warm (interglacial) and cold (glacial) states. Some particularly warm interglacial periods (i.e. 'super-interglacials') occurred under low atmospheric $\mathrm{CO}_{2}$ and may have featured extensive Antarctic ice sheet collapse. Here we focus on an extreme superinterglacial known as Marine Isotope Stage 31 (MIS31), between 1.085 and 1.055 million years ago and is the subject of intense discussion. We reconstructed the first Southern Ocean and Antarctic margin sea surface temperatures (SSTs) from organic biomarkers and used them to constrain numerical ice sheet-shelf simulations. Our SSTs indicate that the ocean was on average $5{ }^{\circ} \mathrm{C}\left( \pm 1.2{ }^{\circ} \mathrm{C}\right)$ warmer in summer than today between $50{ }^{\circ} \mathrm{S}$ and the Antarctic ice margin. Our most conservative ice sheet simulation indicates a complete collapse of the West Antarctic Ice Sheet (WAIS) with additional deflation of the East Antarctic Ice Sheet. We suggest the WAIS retreated because of anomalously high Southern Hemisphere insolation coupled with the intrusion of Circumpolar Deep Water onto the continental shelf under polewardintensified winds leading to a shorter sea ice season and ocean warming at the continental margin. In this scenario, the extreme warming we observed likely reflects the extensively modified oceanic and hydrologic system following ice sheet collapse. Our work highlights the sensitivity of the Antarctic ice sheets to minor oceanic perturbations that could also be at play for future changes.

\section{Keywords}

Super-interglacial, Pleistocene, Paleoceanography, Paleoclimate modeling, Antarctica, Southern Ocean, Organic Geochemistry 
Some geological records suggest that during the early Pleistocene Marine Isotope Stage 31 (MIS31 1.08 to $1.06 \mathrm{Ma}$ ), under preindustrial atmospheric $\mathrm{CO}_{2}$ conditions

(Lüthi et al. 2008; Hönisch et al., 2009), global mean sea level rose by 20 m (Raymo et al., 2006). Recent climate simulations estimate that the global mean temperature increased by $1.2{ }^{\circ} \mathrm{C}$ during boreal summers in the Northern Hemisphere (Justino et al., 2019). The magnitude of the sea level high stand and geological evidence suggest a major retreat of the West Antarctic Ice Sheet (WAIS), part of the East Antarctic Ice Sheet (EAIS) and probably also the Greenland Ice Sheet (Hearty et al., 1999; Raymo et al., 2006; Dutton and Lambeck, 2012; Dutton et al., 2015) during this time. In sediment drill core records from around Antarctica, MIS31 is identified by the abrupt appearance of foraminiferal oozes and coccolith-bearing sediments in the Weddell Sea and Prydz Bay and of bioclastic limestone in the Ross Sea (Bohaty et al., 1998; Scherer et al., 2003; Villa and Wise, 1998; Villa et al., 2008; Villa et al., 2012). This indicates a significant southward migration of the Polar Front (PF), surface ocean warming and open-marine conditions in the Ross and Weddell Seas, with a reduction in sea ice extent relative to the present day (Becquey and Gersonde, 2002; Scherer et al., 2008; Winter et al., 2010; Martinez-Garcia et al., 2010; McKay et al., 2012). To date, elevated ocean surface temperatures have been inferred from paleoecological and sedimentological changes observed in sediment cores around the Antarctic margin (Bohaty et al., 1998; Scherer et al., 2003; 2008; Winter et al., 2010; Dunbar, 2012; Teitler et al., 2005). However, the scarcity of precise surface ocean temperature data has so far limited models from realistically simulating the ice sheet and Southern Ocean responses during MIS31 (Supplementary Information Section 1). Consequently, it has also not been possible to isolate the cause of ice melt and sea 
level rise although an unusual orbital configuration and elevated polar summer insolation have been implicated (Laskar et al., 2004; Scherer et al., 2008).

Ice-sheet/ice-shelf and global climate simulations have highlighted the prominent role the ocean plays in controlling the position of the grounding lines of the WAIS and portions of the EAIS (Jacobs et al., 1992; Dinniman et al., 2016). Here we generate the first SST time series from molecular paleothermometric methods (alkenone unsaturation index $\mathrm{U}^{\mathrm{k}^{\prime}} 37$ - Prahl et al., 1988; and the Long Chain Diol Index LDI Rampen et al., 2012) from Southern Ocean and Antarctic margin deep-sea sediment cores. We then use these sea surface temperature reconstructions to test the scenarios for the AIS retreat during MIS31 using coupled ice-sheet/ice-shelf model (Golledge, et al., 2015).

\section{Material and Methods}

\subsection{Site locations and modern oceanography}

To document the evolution of the sea surface temperatures (SST) in the Atlantic

101 sector of the Southern Ocean during MIS31, we have selected the ODP Site 1094,

102 situated approximately $2^{\circ}$ south of the present Antarctic Polar Front (Schneider-Mor et al., 2008 - Fig. 1). To investigate the SSTs in the peri-Antarctic region, we have selected the IODP Site 1361 (Wilkes Land - Escutia et al., 2011) and the ODP Site 1101 (Antarctic Peninsula - Barker et al., 1999). We supplement our latitudinal

106 temperature dataset with the high resolution alkenone-derived SSTs record from

107 Martinez-Garcia et al. (2010) for the ODP Site 1090 situated North of the modern 108 subantarctic front (SAF) and the $\mathrm{Mg} / \mathrm{Ca}$ measurements on planktic foraminifera from 109 the Cape Roberts Project Site 1 (CRP-1) drilled beneath the northwestern Ross Ice 110 Shelf (Dunbar 2012 - Fig. 1). Sample sites were selected on the basis of previously 111 reported occurrence of MIS31 sediments in the literature. 


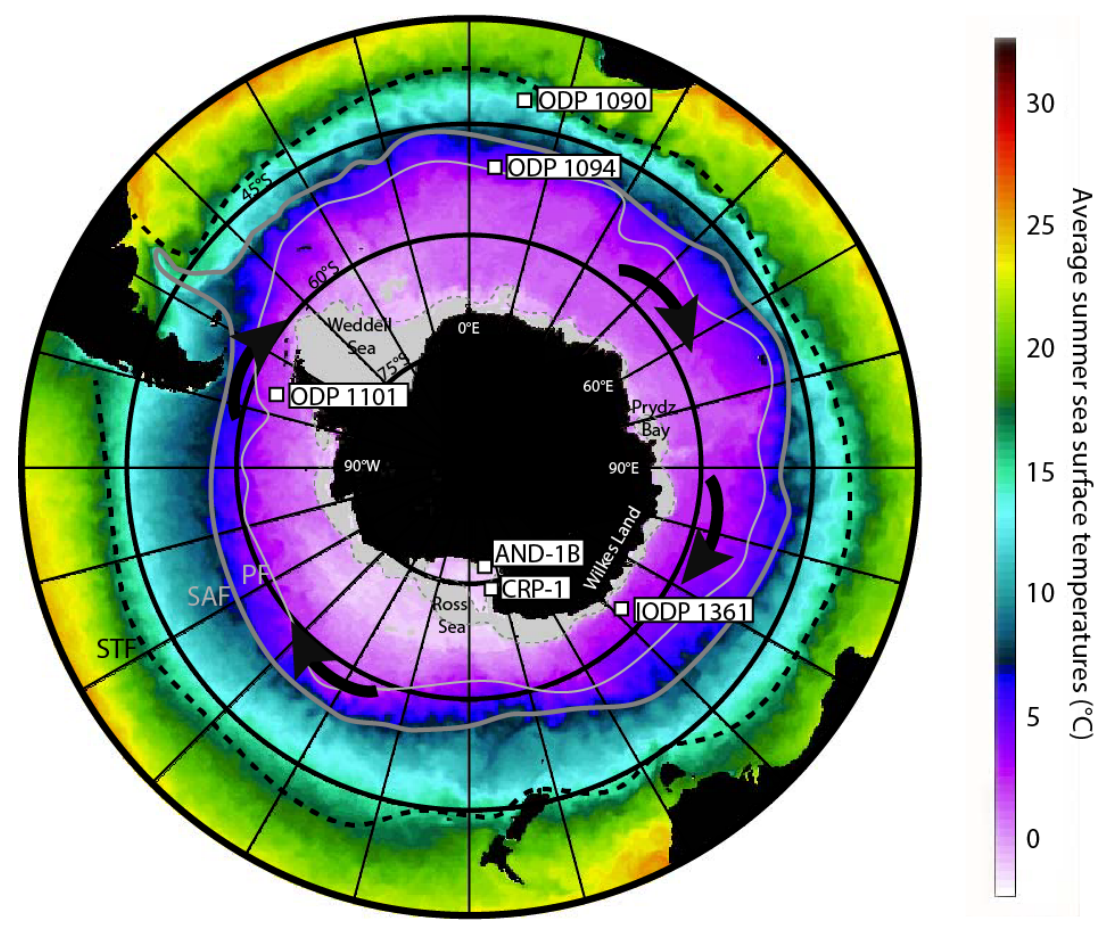

113 Figure 1: Location of the principal ocean frontal systems in the Southern Ocean (Orsi 114 et al., 1995) and drill sites chosen for this study. The modern summer sea surface temperature map was modified after HYCOM Consortium for Data-Assimilative (http://www7320.nrlssc.navy.mil/GLBhycom1-12/skill.html). The general path for the Antarctic Circumpolar Current (ACC) is shown with the black arrows (Orsi et al., 1995). STF: subtropical Front (black dashed)- SAF: Subantarctic Front (dark grey)PF: Polar Front (light grey).

ODP Site $1090\left(4^{\circ}{ }^{\circ 4.8} \mathrm{~S}, 8^{\circ} 5^{2} .9^{\prime} \mathrm{E}\right)$ was drilled on the southern flank of the Agulhas Ridge, at a water depth of 3699 m. It lies within the modern subantarctic waters between the subtropical (STF) and the subantarctic (SAF) fronts in the Atlantic sector of the Southern Ocean. The modern annual SST at this location is $10{ }^{\circ} \mathrm{C}\left(9^{\circ} \mathrm{C}\right.$ in July-September - $11{ }^{\circ} \mathrm{C}$ in January-March; Levitus, 1994). Pleistocene sediment

128 ODP Site $1094\left(\mathbf{5 3}^{\circ} \mathbf{1 0 . 8} \mathbf{S}, \mathbf{5}^{\circ} \mathbf{7 . 8} \mathbf{E}\right)$ is located south of the Polar Front, north of the

129 Weddell Gyre (Antarctic Circumpolar Current (ACC) -boundary) and within the

130 biogenic silica belt (Gersonde et al., 1999). The site is located close to Bouvet Island,

131 in the ice-free Antarctic Zone, at $2807 \mathrm{~m}$ water depth. The investigated sediments 
132 (1094D $11 \mathrm{H}$ to $13 \mathrm{H})$ mainly consist of carbonate bearing diatom ooze, with varying 133 amounts of foraminifera and nannofossils (between $20 \%$ and $45 \%$ ). The mean annual 134 SST in this area is $0.7^{\circ} \mathrm{C}$, with mean temperatures of $0.2^{\circ} \mathrm{C}$ in winter and of $2.5^{\circ} \mathrm{C}$ 135 during austral summer (Levitus, 1994).

136 IODP Site $\mathbf{U} 1361\left(6^{\circ} 4^{\circ} \mathrm{S}, \mathbf{1 4 3 . 8 8}^{\circ} \mathbf{E}\right)$ is located on the Wilkes Land margin, on the 137 eastern levee of the Jussieau sub-marine channel. The mean annual SST in this area is 138 around $0{ }^{\circ} \mathrm{C}$ (Levitus, 1994). Sediments from 1361A-2H consist of silty clay and 139 calcareous silty clay. Sediments from $1361 \mathrm{~A}-3 \mathrm{H}$ are foraminifera-bearing silty clay 140 and diatom-rich silty clay. The occurrence of calcareous nannofossils have been 141 reported in section $5 \mathrm{~W}$. We focused on the interval comprised between $1361 \mathrm{~A}-2 \mathrm{H}-$ $1426 \mathrm{~W}$ and $1361 \mathrm{~A} 3 \mathrm{H} 4 \mathrm{~W}$ because in some discrete intervals planktonic foraminifers were 143 abundant (from Sample $2 \mathrm{H}-\mathrm{CC}$ contains $>90 \%$ ).

144 ODP Site $1101\left(64.37^{\circ} \mathrm{S},-\mathbf{7 0 . 2 6}^{\circ} \mathrm{E}\right)$ is located on the continental rise, west of the 145 Antarctic peninsula, $94 \mathrm{~km}$ offshore the shelf edge. The mean annual SST in this area 146 is around $0{ }^{\circ} \mathrm{C}$ (Levitus, 1994). Between 1101A9H1W100 and 1101A10H3W117 the 147 sediments consist of laminated clayey silts and foraminifera-bearing clayey silts 148 containing well preserved calcareous nannofossils.

149 Cape Roberts Project Site 1 (CRP-1) $\left(\mathbf{7 7 . 0}^{\circ} \mathrm{S}, \mathbf{1 6 3 . 8}^{\circ} \mathbf{E}\right)$ was drilled on the 150 continental shelf in the western Ross Sea near the Transantarctic Mountain belt. 151 Previous studies (Scherer et al., 2008) have focused on the unusual early Pleistocene 152 carbonate rich lithostratigraphic Unit 3.1 corresponding to the MIS31 interglacial. 153 This unique interval contains laminated sediments with abundant diatoms, planktic 154 foraminifera and thoracospherids (calcareous dinoflagellates - Scherer et al., 2008). 
157 We developed a chronology for the IODP Site 1361 from new paleomagnetic 158 measurements performed on u-channel samples at the University of Otago

159 Paleomagnetic Research Facility (OPRF). Our LDI-derived SST data were then

160 converted from depth to the time by linear interpolation between geomagnetic

161 reversals. The alkenone-derived temperatures for the ODP Site 1094 and ODP Site

1621101 were converted from depth to time using the chronologies from shipboard 163 paleomagnetic data.

\subsubsection{IODP Site 1361}

165 U-channel samples were collected at the IODP Core Repository at Texas A\&M

166 University and shipped to the University of Otago's Paleomagnetic Research Facility

167 (OPRF). U-channel samples were collected from the IODP Site 1361 archive half

168 core to establish a more precise magnetostratigraphy. Archive half core sections were

169 demagnetized in fields of $20 \mathrm{mT}$ during the expedition to build an initial age model

170 construction and core characterization. Magnetic moment measurements were made at

$1711 \mathrm{~cm}$ intervals using the $2 \mathrm{G}$ Enterprises pass-through superconducting rock

172 magnetometer which is housed in a $150 \mathrm{nT}$ magnetically shielded room. U-channels

173 were demagnetized in alternating magnetic field increments of $5 \mathrm{mT}$ between $20 \mathrm{mT}$

174 and $50 \mathrm{mT}$, then at $60 \mathrm{mT}, 70 \mathrm{mT}$ and finally at $100 \mathrm{mT}$. Demagnetization data were

175 analysed on orthogonal vector component plots using the PuffinPlot software

176 (Lurcock and Wilson, 2012). Polarity was determined from principal component

177 analyses (PCA, Kirschvink, 1980) of data between the $20 \mathrm{mT}$ and c. $50 \mathrm{mT}$

178 increments which we interpret is the primary depositional remanent magnetizations

179 (DRM). PCAs were typically anchored to the origin with the exception of thin

180 intervals which were offset from the origin where a high coercivity magnetisation

181 prevents complete demagnetisation. Rock magnetic data of these intervals did not 
reveal unusual changes in magnetic mineralogy therefore we suggest that strongly

183 magnetised, high coercivity drop stones may be responsible for the offset origins.

184 Our new magnetostratigraphy does not change the correlation with the GPTS (Tauxe 185 et al., 2012) but does result in more precise placement of reversal boundaries (Fig. 2).

186 Our new magnetostratigraphy places the C1r.1r-C1r.1n (988 ka) boundary (at $17.77 \mathrm{~m}$ $187 \pm 0.03 \mathrm{~m}$, the C1r.1n-C1r.2r (1072 ka) at $19.02 \mathrm{~m} \pm 0.17 \mathrm{~m}$, the top and base of the Cobb 188 Mt (1178-1215 ka, Channell, 2017) at $20.54 \mathrm{~m} \pm 0.06 \mathrm{~m}$ and $20.92 \mathrm{~m} \pm 0.04 \mathrm{~m}$ 189 respectively (Fig. 2). The C1n-C1r.1r (781 ka) transition spans a core break between $1908.1 \mathrm{~m}$ and $14.34 \mathrm{~m}$ (11.22 m mid-point) where the lower contact on core $2 \mathrm{H}$ is 191 affected by coring disturbance and the C1r.2r-C2n (1778 ka) transition occurs at $19232.33 \mathrm{~m} \pm 0.025 \mathrm{~m}$ (Tauxe et al., 2012).

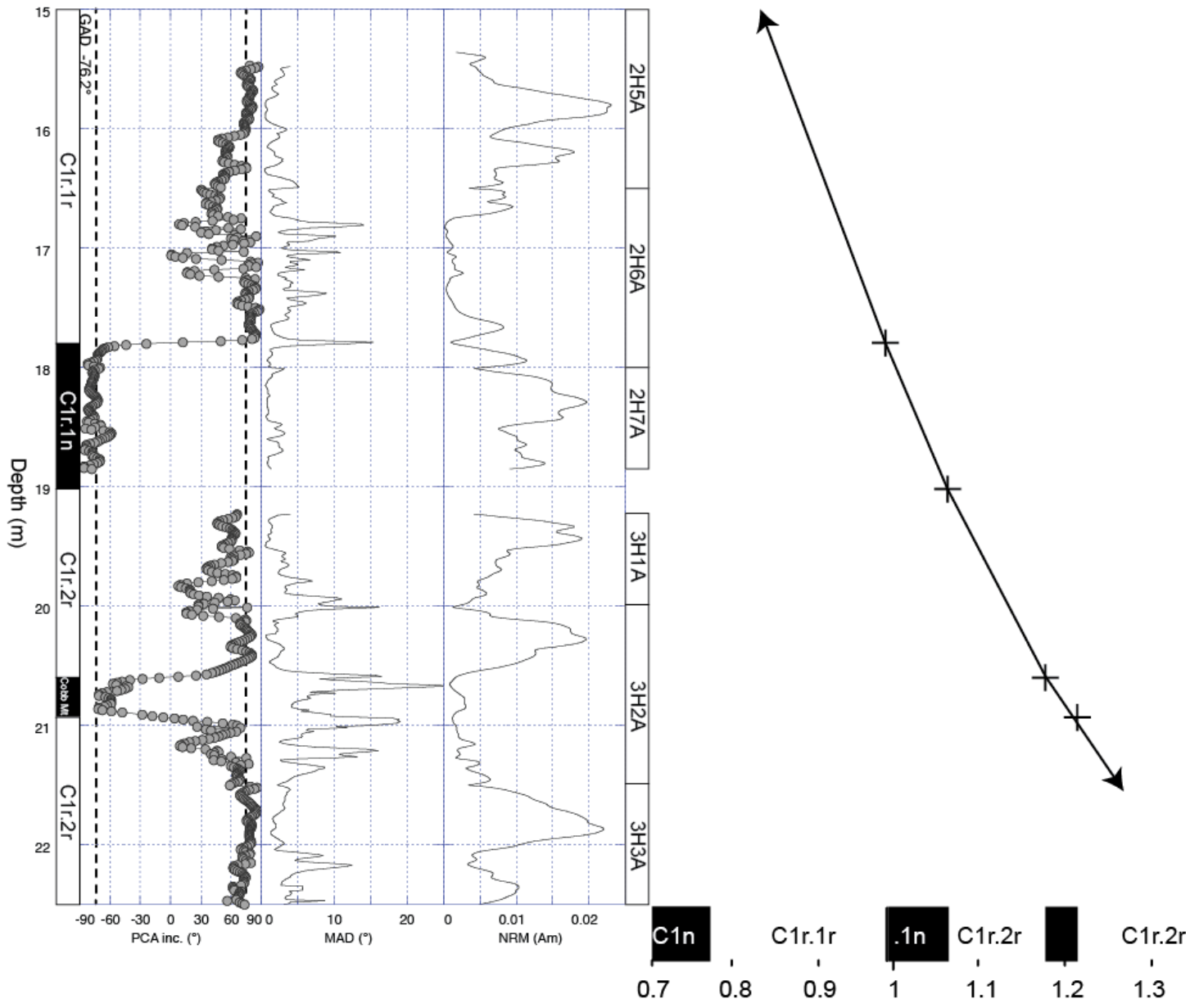

Figure 2: IODP 1361 age model developed in this study.

\subsubsection{ODP Site 1094}


196 The age model of ODP Site 1094A and 1094D was constructed from shipboard

197 paleomagnetic data where the $20 \mathrm{mT}$ demagnetisation step was taken as the 198 characteristic remanent magnetisation as confirmed from complete laboratory 199 demagnetisation of u-channel samples (Channell and Stoner, 2002). The C1n-C1r.1r 200 boundary $(781 \mathrm{ka})$ occurs at $99.61 \mathrm{~m}$, the C1r.1r-C1r.1n (988 ka) boundary at $123 \mathrm{~m}$ $201 \pm 2.22 \mathrm{~m}$, the C1r.1n-C1r.2r (1072 ka) at $129 \mathrm{~m} \pm 0.38 \mathrm{~m}$, and the base of the Cobb Mt $202(1178 \mathrm{ka})$ at $149.6 \mathrm{~m}$.

\subsubsection{ODP Site 1101}

204 We adopted the age model (Acton et al., 2012) based on shipboard analyses and 205 shore-based laboratory analyses from u-channel samples. The C1n-C1r.1r (781 ka) 206 transition occurs at $55.05 \mathrm{~m} \pm 0.01 \mathrm{~m}$, the C1r.1r-C1r.1n (988 ka) at $71.15 \mathrm{~m} \pm 0.19 \mathrm{~m}$, 207 the C1r.1n-C1r.2r (1072 ka) at $76.12 \mathrm{~m} \pm 0.17 \mathrm{~m}$, and the top and base of the Cobb Mt $208(1178-1215 \mathrm{ka}$, Acton et al., 2012) at $81.61 \mathrm{~m} \pm 0.65 \mathrm{~m}$ and $82.53 \mathrm{~m} \pm 0.01 \mathrm{~m}$ 209 respectively. 
211 To reconstruct the latitudinal SST gradient during the MIS31 super-interglacial along 212 a transect from Sub-Antarctic to Antarctic water masses of the Southern Ocean, we 213 used two complementary organic geochemical proxies for SSTs: the alkenone 214 unsaturation ratio (Prahl et al., $1988-\mathrm{U}^{\mathrm{k}}{ }_{37}$ ) and the Long Chain Diol Index (Rampen 215 et al., 2012 - LDI). The use of alkenone thermometry was motivated by the unusual 216 presence of surface-dwelling calcareous nannofossils in 1 Ma-old sediments at 217 extreme southern latitudes around the Antarctic (Scherer et al., 2008; Villa et al., $2182005 ; 2007 ; 2012)$. Specifically, representatives belonging to the alkenone (long-chain 219 unsaturated ketones) producer Noelarhabdaceae family (Emiliania, Gephyrocapsa, 220 Reticulofenetra, Pseudoemiliania, Dictyococcites sp. - Marlowe et al., 1990; Beltran 221 et al., 2007; 2011) were reported at drilling sites located south of the Polar Front (Fig. $2221)$.

223 Although alkenones were detected at Site 1094 (concentrations between 2 and 25 $224 \mathrm{ng} / \mathrm{g}$ ), the concentrations were below detection limits at the Antarctic margin IODP 225 Site U1361. Thus, we chose to use the long chain Diol Index (LDI) to reconstruct the 226 SSTs at the Antarctic margin. This newly developed proxy for paleotemperatures (see 227 Lopes dos Santos et al., 2013; de Bar et al., 2018), is based on the relative abundances 228 of lipids with chain length of 28 and 30 carbon atoms containing two alcohol groups 229 (long chain alkyl 1,13- and 1,15-diols; $\mathrm{C}_{28} 1,13$-diol, $\mathrm{C}_{30} 1,13$-diol and $\mathrm{C}_{30} 1,15$-diol). In 230 the marine environment, these long chain diols have been found in diatoms and 231 marine algae (Rampen et al., 2012). Although the source of the long chain diols is still 232 under discussion, these molecules have existed at least since the Mesozoic era and are 233 ubiquitous in the world ocean from the equator down to very high latitudes $\left(74^{\circ} \mathrm{S}\right)$. 234 The LDI index correlates best with temperature for modern water depths of 0 to $30 \mathrm{~m}$ 
during the warmest months of the year.

236 Alkenone unsaturation ratios were measured on samples from ODP Site 1094D-11H$1 \mathrm{~W}$ to $1094 \mathrm{D}-13 \mathrm{H}-3 \mathrm{~W}$ (between 115.9 and $137.8 \mathrm{~m}$ ) at a resolution of one sample 238 every $30 \mathrm{~cm}$ (temporal resolution of $2.2 \mathrm{kyrs}$ ) and from ODP Site 1101A-9H-2W to 239 1101A-10H-4W (between 68.7 and $80.4 \mathrm{~m}$ ) at a resolution of one sample every $45 \mathrm{~cm}$ 240 (temporal resolution of 7.3 kyrs). For IODP Site 1361, we measured the Long chain 241 diol index (LDI) on 12 samples from 1361A-2H-6W to 1361A-3H-3W (between 17.7 242 and $21.7 \mathrm{~m}$ ) at a resolution of one sample every $35 \mathrm{~cm}$ (temporal resolution of 23 243 kyrs). We found Long chain diols in 10 samples. For both methods, sediment samples 244 (6 to $9 \mathrm{~g}$ ) were freeze-dried, homogenized, and extracted using an automated solvent 245 extractor a Dionex 300 Accelerated Solvent Extractor with dichloromethane and 246 methanol $(9: 1, \mathrm{v} / \mathrm{v})$ at $1500 \mathrm{psi}$ and $100^{\circ} \mathrm{C}$ to obtain a total lipid extract.

247 Alkenones were isolated by silica gel chromatography using solvents of increasing 248 polarity following the procedure of Sicre et al. (2001). The fractions containing 249 alkenones were concentrated, transferred to clean glass-vials and evaporated under 250 nitrogen. Gas chromatographic analyses were performed on a Hewlett Packard 6890 251 gas chromatograph with flame ionization detector using a fused silica capillary 252 column (Rxi-1ms, $50 \mathrm{~m}$ long, $0.32 \mathrm{~mm}$ internal diameter, $0.25 \mu \mathrm{m}$ film thickness). 253 Helium was used as a carrier gas. We have converted the alkenone index into 254 temperature using the Prahl et al. (1988) calibration (see Supplementary Information 255 Section 1.3).

256 Long chain diols were isolated by silica gel chromatography following the procedure 257 of Rampen et al. (2012). Compound identification of the long chain diols was 258 conducted using an Agilent 6890N gas chromatograph (GC) equipped with an Agilent 259 5975B mass selective (MS) detector in selective ion monitoring mode operated at 100 
$260 \mathrm{eV}$ (EI Source). They were separated using a fused silica capillary column (ZB-5MS, $26130 \mathrm{~m}$ long, $0.32 \mathrm{~mm}$ internal diameter, $0.25 \mu \mathrm{m}$ film thickness). The relative 262 abundance of long chain diols was measured using single ion monitoring of $\mathrm{m} / \mathrm{z} 299$, 263313,327 , and 411.

\subsection{Ice sheet/shelves simulations}

\subsubsection{General Circulation Model (GCM) set-up and simulations}

Our RegCM3 experiments were initialised from GENESIS3 GCM simulations previously run at UMass Amherst (DeConto, et al., 2012; DeConto and Kowalewski unpublished). The GCM was run for 30 years to equilibrate, and then for a further 11 years to provide input (initial / boundary conditions) for the RegCM3 regional climate

270 model. To provide appropriate input for RegCM3, GENESIS3 was tuned for orbital 271 forcing, $\mathrm{CO}_{2}$ levels, and ice sheet configuration representative of MIS31. Ice sheet 272 configurations for Neogene interglacials were provided from model results from the 273 Pollard and DeConto (2009) ice sheet model (forced w/ GENESIS3 as well).

\subsubsection{Regional Climate Model (RCM) set-up and simulations}

276 The 11 years -period described above allows for a one-year spinup for the RCM, 277 followed by a ten years model evaluation period. GCM derived boundary conditions 278 were continuously updated every 6 hours of RCM simulation, with fields being 279 interpolated by the 'RegCM3_Polar' package onto the new model grid. No proxy data 280 were used during this phase of climate model set up, but RegCM3 simulations were 281 validated against (1) GCM performance conducted with GENESIS3, and (2) RegCM3 282 forced with NCEP/NCAR reanalysis. Reanalysis driven runs are for the 1990-1999 283 period using observed SST forcing while the Genesis-driven runs employ SST forcing 284 from a slab ocean model. 


\subsubsection{Ice Sheet Model (ISM) set-up and simulations}

287 For our main experiments, we used climate model outputs from GCM experiments in 288 which the ice sheet configuration was similar to present, since our ice sheet model 289 experiments also start from a modern configuration. This avoids the circularity of 290 simulation WAIS collapse by imposing a climatology that has been produced under 291 conditions of a collapsed WAIS. We ran simulations with two different atmospheric 292 greenhouse gas concentrations (280 and $400 \mathrm{ppm} \mathrm{CO}_{2}$ ) to quantify the sensitivity of 293 our results to different background climate states. The climatologies from the regional 294 climate model RegCM3_Polar simulations (RegCM3 adapted to Antarctica; Fig. S3) were imposed at the beginning of each run and the ice sheet was allowed to freely evolve to the new boundary conditions. Ice sheet experiments used the Parallel Ice Sheet Model (PISM) version 0.6, whose dynamical core combines velocity solutions of the shallow shelf and shallow ice approximations for the entire domain (see

299 Supplementary Information Section 2). We ran duplicate experiments both with, and 300 without, the sub-ice shelf grounding line melt interpolation scheme turned on. Once 301 afloat, we imposed two calving mechanisms - one based on horizontal strain rates 302 (Levermann et al., 2012), and another in which a simple minimum thickness criterion $303(200 \mathrm{~m})$ must be satisfied. We ran experiments for two climate scenarios, reflecting 304 atmospheric $\mathrm{CO}_{2}$ concentrations of 280 and $400 \mathrm{ppm}$, and for each of these, ran 305 duplicates with each of the two grounding-line parameterizations. All simulations 306 were run for 10000 years and were initialized from a thermally and dynamically 307 stable configuration used previously (Golledge, et al., 2015; 2017a; 2017b) which 308 closely resembles the present-day ice sheet (Fig. S4 panel a). Ice sheet configurations 309 after 5000 years for each of the experiments are shown in Figure S4. 


\section{Results}

\subsection{Early Pleistocene Southern Ocean sea surface temperatures}

313 Our SST records were generated using the alkenone unsaturation proxy $\left(\mathrm{U}^{\mathrm{k}^{\prime}}{ }_{37}-\right.$ Prahl 314 et al., 1988) in the ice-free Antarctic zone (ODP Site 1094) and in the polar zone ODP 315 Site 1101 and the Long Chain Diol Index (LDI - Rampen et al., 2012) at the IODP

316 Site 1361 (Fig. 3). Two temperature proxies were used because although $\mathrm{U}^{\mathrm{k}^{\prime}}{ }_{37}$ is well317 established, the calcareous nannofossils that produce alkenones (Marlowe et al., 1990; 318 Beltran et al., 2007; 2011) are not always detectable in the coldest high latitude ocean 319 regions. In contrast, the long chain diols used in the LDI index offer a good 320 alternative as they are ubiquitous in the ocean, including at high latitudes $\left(74^{\circ} \mathrm{S}\right)$ and 321 LDI- and $\mathrm{U}^{\mathrm{k}^{\prime}}{ }_{37}$-derived SSTs record similar water depths and seasons (Rampen et al., 322 2012).

323 At ODP Site 1094, our record for the interval between 1.11 Ma and 0.95 Ma shows 324 that the summer SSTs were on average $8.6^{\circ} \mathrm{C}$ (between $5.3{ }^{\circ} \mathrm{C}$ and $10.8^{\circ} \mathrm{C}$ ), which is $3253{ }^{\circ} \mathrm{C}$ warmer than today (Southern Hemisphere Summer months - Levitus, 1994; Fig. 326 3). This indicates sustained long-term elevated ocean surface temperatures in this 327 sector of the Southern Ocean (Fig. 3A). At about $1.076 \mathrm{Ma}$, we identify a $10.8 \pm 1{ }^{\circ} \mathrm{C}$ 328 temperature peak, i.e. $6{ }^{\circ} \mathrm{C}$ warmer than today, which we interpret as the MIS31 329 temperature optimum. Our data shows that during MIS31, SSTs closely track changes 330 in Southern Hemisphere summer insolation with the warmest conditions reached 331 during the highest Southern Hemisphere summer insolation maxima at $1.08 \mathrm{Ma}$ 332 (Laskar et al., 2004). We also observe large magnitude rapid temperature variations, 333 e.g. $5.5^{\circ} \mathrm{C}$ warming between $1082.69 \mathrm{ka}$ and $1082.05 \mathrm{ka}$.

334 At ODP Site 1101 and IODP Site 1361, the age model and sampling resolution is 
335 lower than at ODP Site 1094. However, at both sites, our data show that MIS31

336 corresponds to a summer SST increase of more than $5{ }^{\circ} \mathrm{C}$ compared to today (Levitus, 337 1994; Fig. 3A). The average SST through MIS31 at ODP Site 1101 is $\sim 9.5{ }^{\circ} \mathrm{C}$, 338 peaking at about $\sim 11{ }^{\circ} \mathrm{C}(1.069 \mathrm{Ma})$, which, is $7{ }^{\circ} \mathrm{C}$ warmer than the modern 339 conditions. At IODP Site 1361, (the age model is less well constrained) the average 340 surface water temperature during MIS31 was between 0 and $1^{\circ} \mathrm{C}$, reaching a 341 maximum value of $5{ }^{\circ} \mathrm{C}\left(6^{\circ} \mathrm{C}\right.$ warmer than today - Levitus, 1994). This result is in 342 agreement with the $\mathrm{Mg} / \mathrm{Ca}$ measurements on planktic foraminifera (Dunbar, 2012) 343 and diatom based MIS31 temperature estimates (Scherer et al., 2008 and Scherer 344 comm. pers.) from the Unit 3.1 at CRP-1B who suggests summer SSTs in the Ross 345 Sea were warmer than today by $5-9^{\circ} \mathrm{C}$.

346 Our paleotemperature reconstructions based on organic biomarkers, show that the 347 surface ocean, south of $50{ }^{\circ} \mathrm{S}$, warmed on average by $5{ }^{\circ} \mathrm{C}\left( \pm 1\right.$ to $\left.2{ }^{\circ} \mathrm{C}\right)$ (Fig. 3 and 4$)$, 348 providing the first precise constraints on the maximum surface ocean temperature 349 during MIS31. 


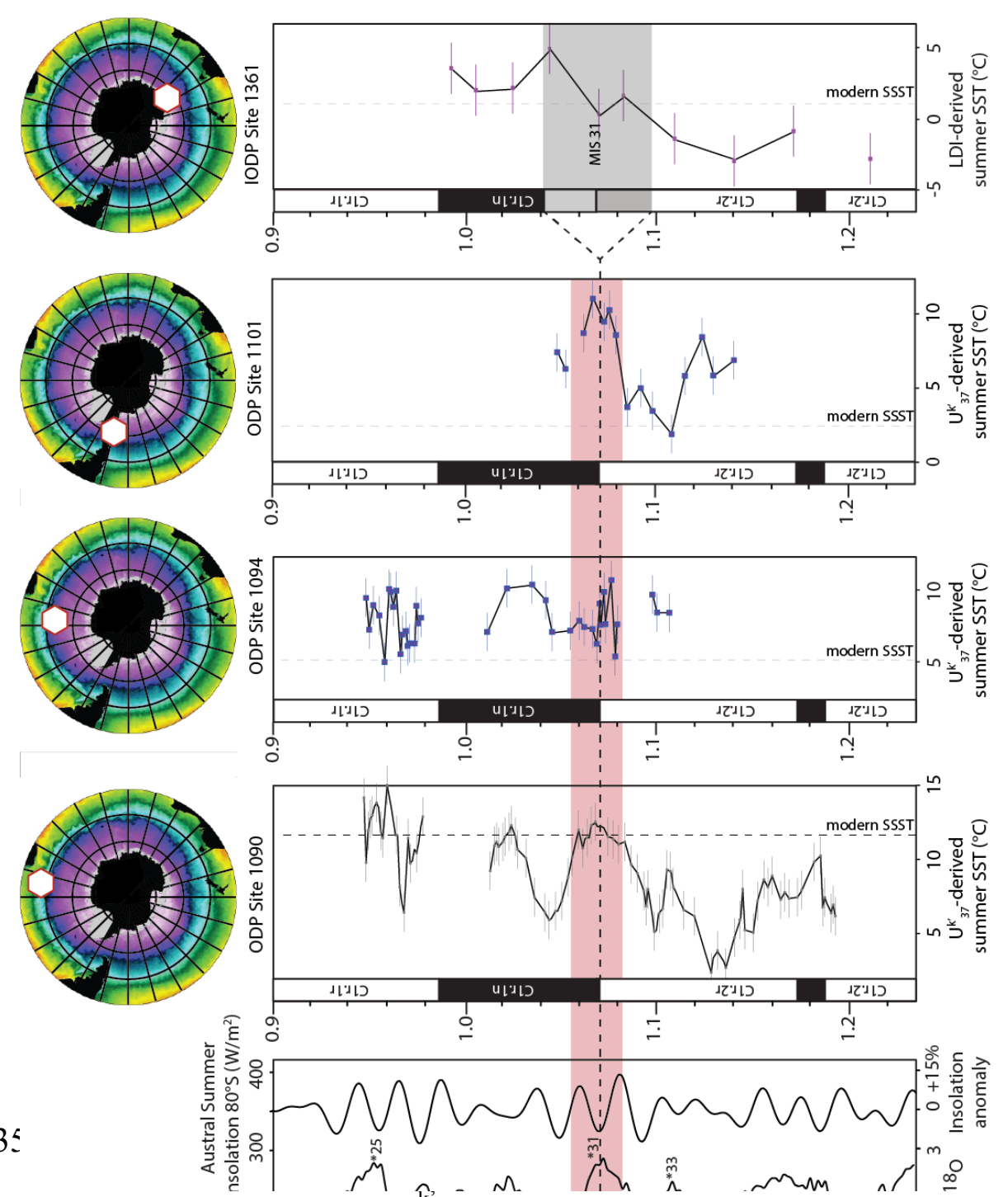

352 Figure 3: Alkenone $\left(\mathrm{U}^{\hat{\mathrm{k}}}{ }_{37}\right)$ and LDI-based SSTs throughout MIS31.

353 We show time series of deep-sea benthic $\delta^{18} \mathrm{O}$ record (\%) (Lisiecki and Raymo, 354 2005), austral summer insolation at $80^{\circ} \mathrm{S}$ and insolation anomaly relative to present 355 (\%increase relative to present; Laskar et al., 2004). Some of the MIS peaks are 356 indicated with the symbol *. MIS31 interglacial duration is highlighted in red. The 357 black dotted horizontal line shows the age of MIS31's peak (*31). Due to the 358 uncertainties on the age model at Site 1361, MIS31 peak is highlighted in grey. Each 359 map indicates the site locations. The error bars correspond to the error of each 360 temperature proxy.

361 Summer southern hemisphere summer season which is here the average temperature 362 for the months DJF

Our temperature record from ODP Site 1094 also indicate strong high-frequency variability within this warm period. 


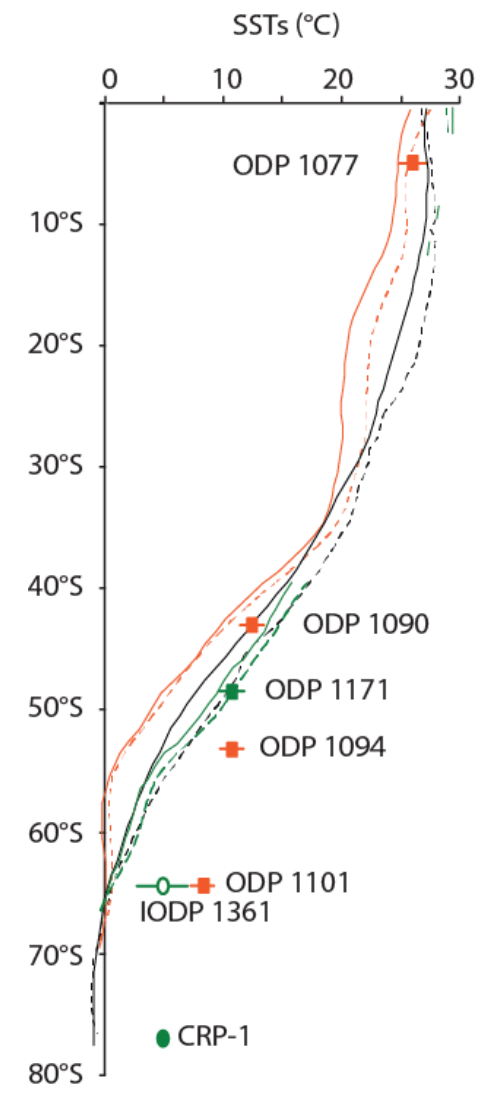

Figure 4: Comparison of the latitudinal sea surface temperature gradients during MIS31 warmth with modern conditions. MIS31 temperature data for Site ODP 1077 is from Schefus et al. (2004), for ODP Site 1171 from Beltran et al. (2016) and for CRP-1 from Dunbar (2012). The orange and green bars represent respectively the error bars for alkenone and LDI measurements.

Black dashed line: Modern Annual Southern Ocean SST - Green dashed line: Modern Annual Atlantic Ocean SST - Orange dashed line: Modern Annual Pacific Ocean SST - Green line: Modern Austral Summer Southern Ocean SST - Orange line: Modern Austral Summer Atlantic Ocean SST Black line: Modern Austral Summer Pacific Ocean SST.

When comparing our high latitude records with the lower latitude alkenone-derived SSTs at the subantarctic ODP Site 1090 and the equatorial ODP Site 1077 (Schefus et al., 2004 - Fig. 4), we observe a significant polar amplification during MIS31, resulting in a reduced latitudinal SST gradient (Scherer et al., 2008; Martinez-Garcia et al., 2010; Dunbar, 2012; Beltran et al., 2016) of $\sim-0.3^{\circ} \mathrm{C} /{ }^{\circ}$ latitude (Fig. 4).

374 To investigate the degree of ice sheet retreat in relation to our SST records we 375 conducted a suite of numerical simulations that use climate fields from a regional 376 climate model (DeConto et al., 2012 - RCM, Supplementary Section 2). Our proxy 377 data were critical to the simulations because they were the quality assurance that the 378 simulations were capturing the correct magnitude of warming. We used the Parallel 379 Ice Sheet-Model, which is an open source three-dimensional thermodynamic coupled 380 ice sheet/ice-shelf model. Our RCM simulation represents a time slice reconstruction 
rather than a transient prediction, but considers two atmospheric $\mathrm{CO}_{2}$ concentration

382 scenarios - $280 \mathrm{ppm}$ and $400 \mathrm{ppm}$ - so that the sensitivity of the ice sheet to 383 atmospheric composition can be assessed (Supplementary Section 2.2). Using these 384 two scenarios as inputs, we also then combined each one with either a conservative 385 grounding line scheme (no SGm) or a more dynamic grounding line (SGm). Because 386 our climate forcing is not transient, we were interested primarily in seeing whether 387 significant ice sheet impacts could occur within relatively short time periods 388 (centuries to a millennium) of warmth, since our proxy data indicate that such 389 temperatures are not likely to have been sustained for the entire interglacial.

390 In all simulations, the WAIS melted within a few centuries (Fig. 5B, C, D, E and F) 391 whereas the EAIS responded more slowly (Supplementary Section 2.3). The 392 simulations revealed that regardless of the grounding line scenario and $\mathrm{CO}_{2}$ forcing, 393 no significant difference in the spatial extent of ice loss is observed after 5kyr (Fig. 394 S4).
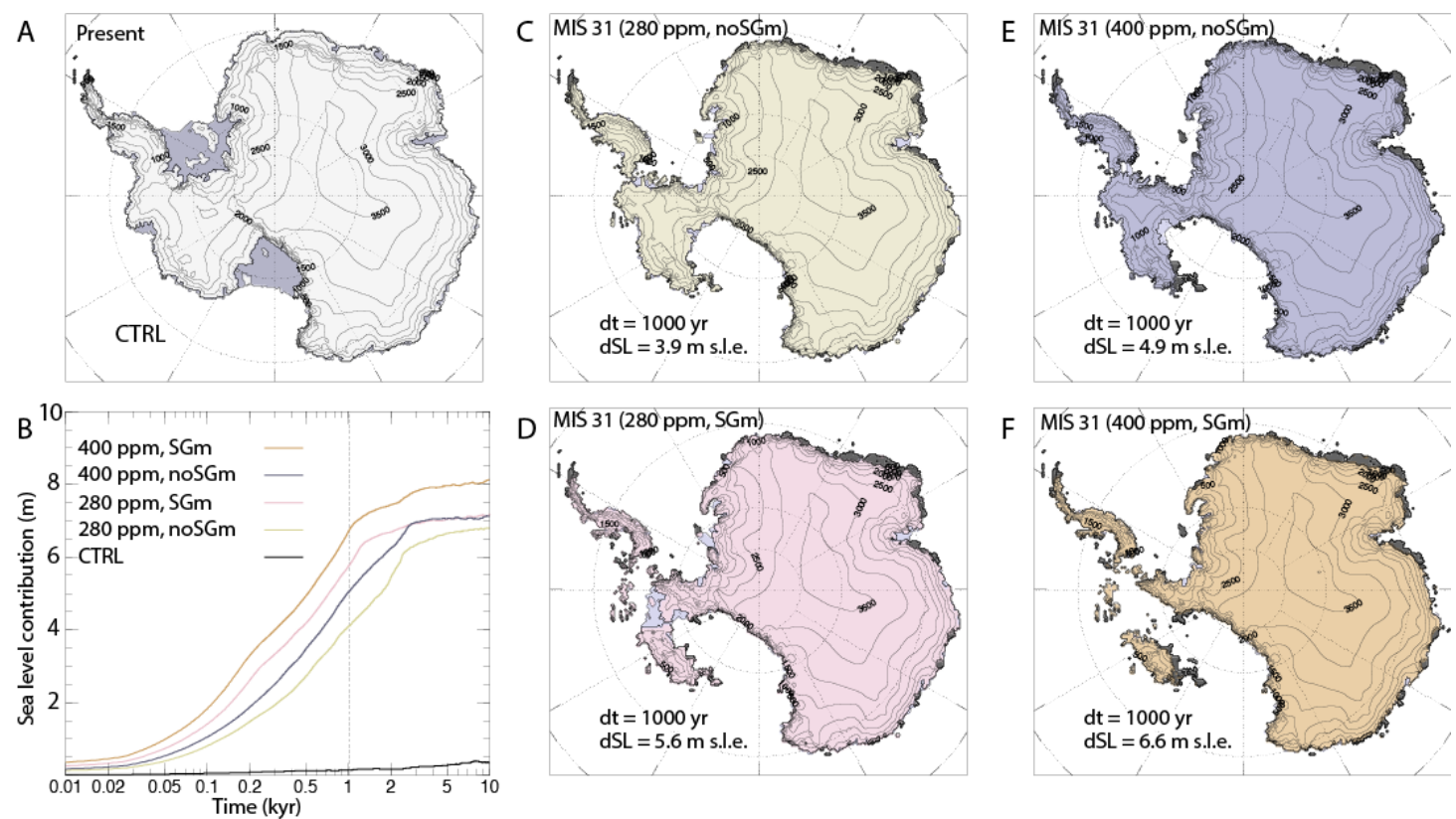

Figure 5: Snapshots of ice distribution for ice sheet experiment runs of 1000 years (dt). We present the results using a conservative groundling line behaviour (no SGm, C. and E.), a dynamic grounding line (SGm, D. and F.), each with two extreme $\mathrm{CO}_{2}$ scenarios (280 ppm and $400 \mathrm{ppm})$. A. represents the modern ice distribution and B. is 
400 the sea level contribution from ice melting through time. dSL is the sea level increase 401 expressed in s.l.e (sea level equivalent).

402 Our results indicate that 2-m of sea-level rise from ice loss occur within a few

403 centuries (Fig. 5B) and that persistent elevated SSTs would cause complete collapse

404 of the WAIS, with additional thinning around the margins of the EAIS (i.e. the Wilkes

405 Land basin, Weddell Sea, Aurora Basin).

406 4. Discussion and conclusions

407 Our temperature reconstructions indicate proximal ice margin summer SSTs of $4-5{ }^{\circ} \mathrm{C}$ 408 in East and $9{ }^{\circ} \mathrm{C}$ in West Antarctica $\left(5-7^{\circ} \mathrm{C}\right.$ warmer than today) during MIS31, in 409 agreement with Scherer et al (2008), Villa et al. (2008, 2012). Those temperatures are 410 not compatible with the presence of a significant West Antarctic ice sheet (Joughin 411 and Alley, 2011; Liu et al., 2015 - Fig. 5).

412 The causes of the MIS31 extreme warmth under pre-industrial atmospheric $\mathrm{CO}_{2}$ 413 conditions are still unclear. MIS31 interglacial coincides with a time of high obliquity 414 and eccentricity, which led to strong high latitude austral summer insolation 415 anomalies. How much of the ocean warming observed in our records can be attributed 416 to the high summer insolation? Simulations of previous interglacials (Yin and Berger, 417 2012) showed that reduction of summer sea ice increases the sensitivity of southern 418 high latitudes to solar radiation (Yin and Berger, 2012) resulting in warming of 419 surface waters. According to Yin and Berger (2012), during interglacials with similar 420 obliquity values as MIS31, increased insolation contributed to a maximum mean 421 annual warming of only $0.5{ }^{\circ} \mathrm{C}$ of the high southern hemisphere latitudes. As a 422 consequence, high insolation alone cannot account for the extreme ocean 423 temperatures we observe around Antarctica during MIS31. We argue here that the 424 exceptional warmth is the consequence of an increasingly stratified ocean due to 425 freshwater input from ice loss (Golledge et al., 2014) rather than a trigger for ice loss. 
426 Reduced surface ocean salinity is supported by the diatom assemblage composition at

427 CRP-1 with increased abundance of Chaetoceros spp. correlated to the insolation 428 maximum at $1.08 \mathrm{Ma}$ (Scherer et al., 2008). The calcareous nannofossil assemblage 429 composition at ODP Site 1094 also support this hypothesis with a clear increase of 430 Helicosphaera carteri and Syracosphaera spp. (Flores and Sierro, 2007; Scherer et 431 al., 2008).

432 We suggest ice margin retreat was caused by circulation changes in Antarctic coastal 433 waters, as a result of changes in wind patterns (Gille et al., 2016). A poleward shift of 434 the Southern Hemisphere Westerly Winds (SHWW) is seen in the decrease of aeolian 435 dust in the Subantarctic Zone (Martinez-Garcia et al., 2010 - ODP Site 1090), raising 436 the possibility that a wind-induced subsurface warming at the Antarctic margin took 437 place during MIS31. In the modern ocean, cold Antarctic shelf waters are separated 438 from warmer Circumpolar Deep Water (CDW) further offshore by the Antarctic 439 Slope Front (ASF - Jacobs, 1991), a well-marked density front that is primarily 440 maintained through coastal downwelling induced by the prevailing coastal easterly 441 winds (Sverdrup, 1953). Ocean model simulations have demonstrated that a poleward 442 shift of the SHWW reduces the extent and strength of the coastal easterlies and can 443 produce strikethrough advective warming of subsurface waters at the Antarctic 444 margin, via a weakening of the ASF that allows CDW to intrude onto the shelf 445 (Schmidtko et al., 2014; Gille et al., 2016). Heat from the CDW would subsequently 446 trigger basal melting of the ice shelves (Dinniman et al., 2016). Additional 447 observational (Schmidtko et al., 2014; Dutrieux et al., 2014) and modelling evidence 448 (Thoma et al., 2008; Dinniman et al., 2012) also implicates the SHWW in regulating 449 poleward transport of warm CDW onto the Antarctic continental shelf in the modern450 day ocean, and it therefore seems plausible that this onshore CDW transport was 
451 enhanced by poleward-intensified winds during MIS31 (Martinez-Garcia et al., 2010).

452 Precise dynamics underlying such wind-driven CDW inflow however remain an area 453 of active research (Gille et al., 2016).

454 We propose that the exceptional surface ocean warming during the MIS31 super455 interglacial occurred in two steps (Fig. 6). [Step 1] The unusual MIS31 orbital 456 configuration resulted in an extended period ( $\sim 2000$ years) of warm and long-lasting 457 summer seasons that caused mild warming of Southern Ocean surface waters and the 458 reduction of sea ice development or survival. Concomitantly, the prevailing Southern 459 Hemisphere Westerly Winds and the easterly coastal winds migrated to the south 460 (Fig. 6). The poleward shifted winds warmed the coastal waters, thus bringing heat 461 southwards thereby initiating basal melting of ice shelves and the retreat of the 462 marine-based grounding lines. Our numerical ice sheet model demonstrates that a 0.5 $463{ }^{\circ} \mathrm{C}$ ocean warming at the ice margin for c. 200 years is sufficient to cause ice retreat 464 and that most of it can occur in less than 2000 years. [Step 2] The surface warming in 465 the coastal regions $\left(9.5^{\circ} \mathrm{C}\right.$ at ODP Site 1101 and $5^{\circ} \mathrm{C}$ at IODP Site 1361$)$ could only 466 take place after complete loss of the WAIS (Fig. 6) and would likely be amplified by 467 ocean stratification feedbacks. 

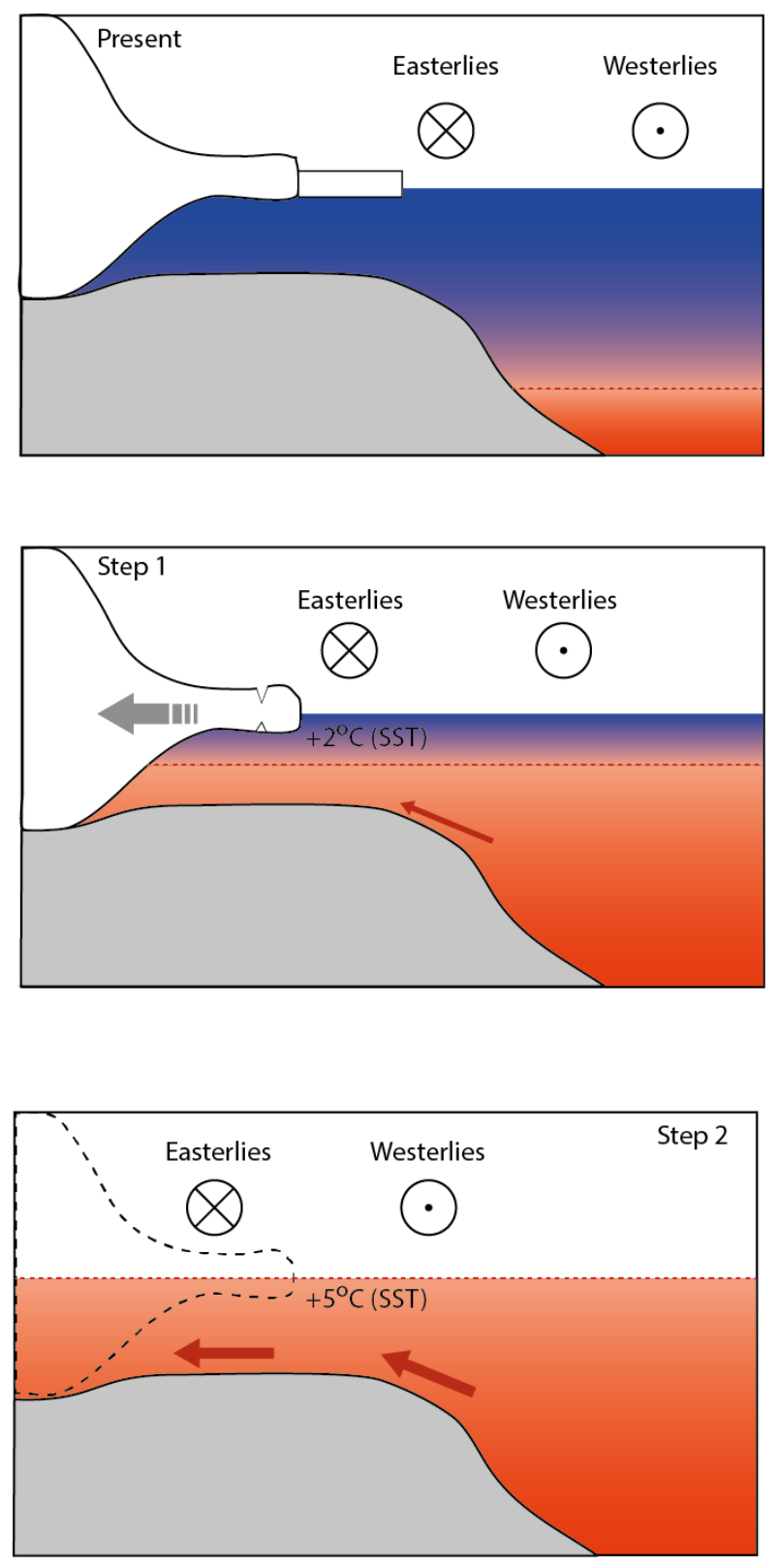

469 Figure 6: Schematic evolution of ice retreat during MIS31 in response to poleward 470 wind shift and subsequent ocean warming. Step 1 shows the increased advection of 471 warmer deep waters (red arrow, see Pedro et al., 2016), Step 2 represents the run over 472 ice melting at the maximum of MIS31 warmth.

474 Our new data from the Antarctic sedimentary records demonstrate that a moderate 475 surface ocean warming is sufficient to initiate a major West Antarctic Ice Sheet 476 retreat. We also show that even after 10000 years of persistent elevated SSTs, marine 477 basins of East Antarctica remain glaciated, with the majority of the EAIS sea-level 478 contribution coming from coastal thinning around Dronning Maud Land. That the 
marine basins of EAIS were not destabilized at MIS31 suggests that atmospheric

480 warming (as simulated in the RCM) at that time was insufficient to bring about 481 significant surface melting, thinning, and retreat from coastal pinning points 482 (Golledge et al., 2017b).

483 Future research should focus on further documenting high latitude Southern Ocean 484 SSTs using molecular thermometry to identify critical ocean temperatures that led to 485 major Antarctic ice retreats in the past under varying atmospheric $\mathrm{CO}_{2}$ and orbital 486 conditions.

\section{Acknowledgments}

489 This project was funded by the French Institut National des Sciences de l'Univers and 490 the New Zealand Antarctic Research Institute contracts LEFE/IMAGO 2013, NZARI 491 2015-3 to Catherine Beltran and a University of Otago Research Grant to Christian 492 Ohneiser. The research used samples provided by the International Ocean Drilling 493 Program, which is sponsored by the US NSF and participating countries under 494 management of Joint Oceanographic Institutions. We are grateful to the International 495 Ocean Drilling Program curatorial staff at the Bremen Core Repository (BCR 496 University of Bremen, Germany) and the Gulf Coast Repository (GCR - Texas A\&M 497 University, College Station, Texas) for assistance with sample collection and 498 processing of sample requests.

499 We are grateful to Maria Rugenstein for providing climate model outputs. Nicholas R. 500 Golledge acknowledges support from the Royal Society Te Aparangi under contract 501 VUW1501. 
Acton, G., Guyodo, Y., Brachfeld, S., 2012. Magnetostratigraphy of sediment drifts on the continental rise of West Antarctica (ODP Leg 178, Sites 1095, 1096 and 1101). Proceedings of the Ocean Drilling Program: Scientific Results 178, 1-61.

Barker, P.F., Camerlenghi, A., Acton, G.D., et al., 1999. Proc. ODP, Init. Repts. 178. http://www -odp.tamu.edu/publications/178_IR/178TOC.HTM.

Becquey, S. and Gersonde, R., 2002. Past hydrographic and climatic changes in the Subantarctic Zone - the Pleistocene record from ODP Site 1090. Palaeogeogr. Palaeoclimatol. Palaeoecol. 182, 221-239.

Beltran, C., de Rafélis, M., Minoletti, F., Renard, M., Sicre, M-A., Ezat, U., 2007. Coccolith $\delta^{18} \mathrm{O}$ and alkenone records in Middle Pliocene orbitally controlled deposits: High-frequency temperature and salinity variations of sea surface water. Geochem. Geophys. Geosyst. 8. https://doi.org/10.1029/2006GC001483.

Beltran, C., Flores, J-A., Sicre, M-A. Baudin, F., Renard, M., de Rafélis, M., 2011. Long-chain alkenones in the Early Pliocene Sicilian sediments (Trubi Formation Punta di Maiata section): implications for the alkenone paleothermometry. Palaeogeo. Palaeoclim., Palaeoeco. 308(3), 253-263. https://doi.org/10.1016/j.palaeo.2011.03.017.

Beltran, C., Ohneiser, C., Hageman, K.J., Scanlan, E., 2016. Evolution of the Southwestern Pacific surface waters during the Early Pleistocene. New Zealand Journal of Geology and Geophysics 59:4, 514-521. https://doi.org/10.1080/00288306.2016.1195756.

Bohaty, S., Scherer, R., Harwood, D.M., 1998. Quaternary diatom biostratigraphy and paleoenvironments of the CRP-1 drillcore, Ross Sea, Antarctica. Terra Antarctica 5, 431-453.

Channell, J., 2017. Cobb Mountain Subchron recorded at IODP Site U1306 (Eirik Drift, off SE Greenland). Geophysical Journal International 209(3), 1389-1397.

Channell, J. and Stoner, J., 2002. Plio-Pleistocene magnetic polarity stratigraphies and diagenetic magnetite dissolution at ODP Leg 177 Sites (1089, 1091, 1093 and 1094). Marine Micropaleontology 45(3-4), 269-290.

de Bar, M.W., Stolwijk, D.J., McManus, J.F., Sinninghe Damsté, J.S., Schouten, S., 2018. A Late Quaternary climate record based on long-chain diol proxies from the Chilean margin. Clim. Past 14, 1783-1803. https://doi.org/10.5194/cp-14-17832018.

DeConto, R.M., Pollard, D., Kowalewski, D., 2012. Modeling Antarctic ice sheet and climate variations during Marine Isotope Stage 31. Global and Planetary Change 88-89, 45-52.

Dinniman, M.S., Klinck, J.M., Hofmann, E.E., 2012. Sensitivity of Circumpolar Deep Water transport and ice shelf basal melt along the West Antarctic Peninsula to changes in the winds. Journal of Climate 25(4),799-4. https://doi.org/10.1175/ JCLI-D-11-00307.1.

Dinniman, M.S., Asay-Davis, X.S., Galton-Fenzi, B.K., Holland, P.R., Jenkins, A., Timmermann, R., 2016. Modeling ice shelf/ocean interaction in Antarctica: A review. Oceanography 29(4), 144-153.

Dunbar, G.B., 2012. Mg/Ca sea surface temperatures during the Marine Isotope Stage 31 collapse of the Ross Ice Shelf. EGU General Assembly 2012, Vienna, Austria., 14473.

Dutrieux, P., De Rydt, J., Jenkins, A., Holland, P.R., Ha, H.K., Lee, S.H., Steig, E.J., Ding, Q., Abrahamsen, E.P., Schröder, M., 2014. Strong sensitivity of Pine Island 
ice-shelf melting to climatic variability. Science 343,174-178. https://doi.org/10.1126/science.1244341.

Dutton, A. and Lambeck, K., 2012. Ice Volume and Sea Level During the Last Interglacial. Science 337. https://doi.org/10.1126/science.1205749.

Dutton, A., Carlson, A.E., Long, A.J., Milne, G.A., Clark, P.U., DeConto, R., Horton, B.P., Rahmstorf, S., Raymo, M.E., 2015. Sea-level rise due to polar ice-sheet mass loss during past warm periods. Science 349. https://doi.org/10.1126/science.aaa4019.

Expedition 318 Scientists, 2011. Site U1361. In Escutia, C., Brinkhuis, H., Klaus, A., and the Expedition 318 Scientists, Proc. IODP, 318: Tokyo (Integrated Ocean Drilling Program Management International, Inc.). https://doi.org/10.2204/ iodp.proc.318.109.2011.

Gersonde, R. et al., 1999. Proceedings of the Ocean Drilling Program, 177 Initial reports. Proceeding of the Ocean Drilling Program 177. https://doi.org/10.2973/odp.proc.ir.177.1999.

Gille, S.T., McKee, D.C., Martinson, D.G., 2016. Temporal changes in the Antarctic Circumpolar Current: Implications for the Antarctic continental shelves. Oceanography 29(4), 96-105 https://doi.org/10.5670/oceanog.2016.102.

Golledge, N.R. Menviel, L., Carter, L., Fogwill, C.J., England, M.H., Cortese, G., Levy, R.H., 2014. Antarctic contribution to meltwater pulse 1A from reduced Southern Ocean overturning. Nature communications 5, 5107. https://doi.org/10.1038/ncomms6107.

Golledge, N.R., Kowalewski, D.E., Naish, T.R., Levy, R.H., Fogwill, C.J., Gasson, E.G.W., 2015. The multi-millenial Antarctic commitment to future sea-level rise. Nature 526. https://doi.org/10.1038/nature15706.

Golledge, N.R., Levy, R.H., McKay, R.M. Naish, T.R., 2017a. East Antarctic ice sheet most vulnerable to Weddell Sea warming. Geophys. Res. Lett. 44. https://doi.org/10.1002/2016GL072422.

Golledge, N.R., Thomas, Z.A., Levy, R.H., Gasson, E.G.W., Naish, T.R., McKay, R.M., Kowalewski, D.E., Fogwill, C.J., 2017b. Antarctic climate and ice sheet configuration during the early Pliocene interglacial at 4.23 Ma. Clim. Past 13, 117. https://doi.org/10.5194/cp-13-1-2017.

Hearty, P.J., Kindler, P., Cheng, H., Edwards, R.L., 1999. A +20m middle Pleistocene sea-level high-stand (Bermuda and the Bahamas) due to partial collapse of Antarctic ice. Geology 27, 375-378.

Hönisch, B., Hemming, N.G., Archer, D., Siddall, M., McManus, J.F., 2009. Atmospheric carbon dioxide concentration across the Mid-Pleistocene Transition. Science 324, 1551-1554. https://doi.org/10.1126/science.1171477.

Jacobs, S.S., 1991. On the nature and significance of the Antarctic Slope Front. Mar. Chem. 35, 9-24.

Jacobs, S.S., Hartmut, H., Doake, C.S.M., Jenkins, A., Frolich, R.M., 1992. Melting of ice shelves and the mass balance of Antarctica. J. Glaciol. 38, 375-387.

Joughin, I. and Alley, R.B., 2011. Stability of the West Antarctic ice sheet in a warming world. Nature Geosci. 4, 506-513.

Justino, F., Kucharski, F., Lindemann, D., Wilson, A., Stordal, F., 2019. A modified seasonal cycle during MIS31 super-interglacial favors stronger interannual ENSO and monsoon variability. Clim. Past 15, 735-749. https://doi.org/10.5194/cp-15735-2019, 2019. 
Kirschvink, J.L., 1980. The least-squares line and plane and the analysis of paleomagnetic data. Geophysical Journal of the Royal Astronomical Society 62(3), 699-718.

Laskar, J., Robutel, P., Joutel, F., Gastineau, M., Correia, A.C.M., Levrard B., 2004. A long-term numerical solution for the insolation quantities of the Earth. A. \& A. 428, 261-285. https://doi.org/10.1051/0004-6361:20041335.

Levermann, A., Albrecht, T., Winkelmann, R., Martin, M. A., Haseloff, M., Joughin, I., 2012. Kinematic first-order calving law implies potential for abrupt ice-shelf retreat. Cryosphere 6, 273-286. https://doi.org/10.5194/tc-6-273-2012.

Levitus, S.E., 1994. Climatological atlas of the world ocean, NOAA Professional Paper 13, US Government Printing Office, Washington DC.

Lisiecki, L.E. and Raymo, M.E., 2015. A Pliocene-Pleistocene stack of 57 globally distributed benthic $\delta^{18} \mathrm{O}$ records. Paleoceanography 20, PA1003. https://doi.org/10.1029/2004PA001071.

Liu, Y. Moore, J.C., Cheng, X., Gladstone, R.M., Bassis, J.N., Liu, H., Wen, J., Hui, F., 2015. Ocean-driven thinning enhances iceberg calving and retreat of Antarctic ice shelves. Proc. Natl Acad. Sci. USA 112, 3263-3268.

Lopes dos Santos, R.A., Spooner, M.I., Barrows, T.T., De Deckker, P., Sinninghe Damsté J.S., Schouten, S., 2013. Comparison of organic $\left(\mathrm{U}^{\mathrm{K}}{ }_{37}, \mathrm{TEX}^{\mathrm{H}}{ }_{86}, \mathrm{LDI}\right)$ and faunal proxies (foraminiferal assemblages) for reconstruction of late Quaternary sea surface temperature variability from offshore southeastern Australia. Paleoceanography 28, 377-387. https://doi.org/10.1002/palo.20035

Lurcock, P.C. and Wilson, G.S., 2012. PuffinPlot: A versatile, user-friendly program for paleomagnetic analysis. Geochemistry, Geophysics, Geosystems 13(6).

Lüthi, D., Le Floch, M., Bereiter, B., Blunier, T., Barnola, J-M., Siegenthaler, U., Raynaud, D., Jouzel, J., Fischer, H., Kawamura, K., Stocker, T.F., 2008. Highresolution carbon dioxide concentration record $650,000-800,000$ years before present. Nature 453, 379-382. https://doi.org/10.1038/nature06949.

Maiorano, P., Marino, M., Flores, J-A., 2009. The warm interglacial isotope Stage 31: evidences from the calcareous nannofossil assemblages at Site 1090 (Southern Atlantic). Marine Micropaleontology 71, 166-175.

Marlowe, I.T., Brassell, S.C., Eglinton, G., Green, J.C., 1990. Long-chain alkenones and alkyl alkenoates and the fossil coccolith record of marine sediments. Chem. Geol. 88, 349-375.

Martinez-Garcia, A., Rosell-Melé, A., McClymont, E.L., Gersonde, R., Haug, G.H., 2010. Subpolar Link to the Emergence of the Modern Equatorial Pacific Cold Tongue. Science 328, 1550-1553. https://doi.org/ 10.1126/Science.1184480.

McKay, R.M. Naish, T., Powell, R., Barrett, P., Talarico, F., Kyle, P., Monien, D., Kuhn, G., Jackolski, C., Williams, T., 2012. Pleistocene variability of Antarctic Ice Sheet extent in the Ross Embayment. Quaternary Science Reviews 34, 93-112.

Orsi, A.H., Whitworth, T., Nowlin, W.D., 1995. On the meridional extent and fronts of the Antarctic Circumpolar Current. Deep-Sea Res. I 42, 641-673.

Pedro, J.B., Martin, T., Steig, E.J., Jochum, M., Park, W., Rasmussen, S.O., 2016. Southern Ocean deep convection as a driver of Antarctic warming events. Geophysical Research Letters 43, 2192-2199.

Pollard, D. and DeConto, R.M., 2009. Modeling West Antarctic Ice Sheet growth and collapse through the last 5 million years. Nature 458, 329-332.

Prahl, F.G., Muehlhausen, L.A., Zahnle, D.L., 1988. Further evaluation of long-chain alkenones as indicators of paleoceanographic conditions. Geochim. Cosmochim. Acta 52, 2303-2310. 
Rampen, S.W., Willmott, V., Kim, J-H., E. Uliana, Mollenhauer, G., Schefuß, E., Sinninghe Damsté, J.S., Schouten, S., 2012. Long chain 1,13- and 1,15-diols as a potential proxy for palaeotemperature reconstruction. Geochimica et Cosmochimica Acta 84, 204-216.

Raymo, M.E., Lisiecki, L., Nisancioglu, K., 2006. Plio-Pleistocene ice volume, Antarctic climate and the global $\delta^{18} \mathrm{O}$ record. Science 313, 492-495.

Schefuß, E., Sinninghe Damste, J.S.S., Jansen, J.H.F., 2004. Forcing of tropical Atlantic sea surface temperatures during the mid-Pleistocene transition. Paleoceanography 19. https://doi.org/10.1029/2003PA000892.

Scherer, R.P., Harwood, D.M., Taviani, M., Bohaty, S.M., Roberts, A.P., 2003. Marine Isotope Stage 31 (1.07 Ma): an extreme interglacial in the Antarctic nearshore zone. Geophys. Res. Abstr. 5, 11710.

Scherer, R.P., Bohaty, S.M., Dunbar, R.B., Esper, O., Flores, J-A., Gersonde, R., Harwood, D.M., Roberts, A.P., Taviani, M., 2008. Antarctic records of precessionpaced insolation-driven warming during early Pleistocene Marine Isotope Stage 31. Geophys. Res. Letters 35, L03505. https://doi.org/10.1029/2007GL032254.

Schmidtko, S., Heywood, K.J., Thompson, A.F., Aoki, S., 2014. Multidecadal warming of Antarctic waters. Science 346, 1227-1231.

Schneider-Mor, A., Yam, R., Bianchi, C., Kunz-Pirrung, M., Gersonde, R., Shemesh, A., 2008. Nutrient regime at the siliceous belt of the Atlantic sector of the Southern Ocean during the past 660ka. Paleoceanography 23, PA3217. https://doi.org/10.1029/2007PA001466.

Sicre, M.A., Ternois, Y., Paterne, M., Martinez, P., Bertrand, P., 2001. Climatic changes in the upwelling region off Cap Blanc, NW Africa, over the last 70 kyrs, a multi-biomarker approach. Organic Geochemistry 32, 981-990.

Sverdrup, H., 1953. The currents off the coast of Queen Maude Land. Norw. J. Geogr. $14,1-4$.

Tauxe, L., Stickley, C.E., Sugisaki, S., Bijl, P.K., Bohaty, S.M., Brinkhuis, H., Escutia, C., Flores, J-A., Houben, A.J.P., Iwai, M., Jiménez-Espejo, F., McKay, R., Passchier, S., Pross, J., Riesselman, C.R., Röhl, U., Sangiorgi, F., Welsh, K., Klaus, A., Fehr, A., Bendle, J.A.P., Dunbar, R., Gonzàlez, J., Hayden, T., Katsuki, K., Olney, M.P., Pekar, S.F., Shrivastava, P.K., van de Flierdt, T., Williams, T., Yamane, M., 2012. Chronostratigraphic framework for the IODP Expedition 318 cores from the Wilkes Land Margin: constraints for paleoceanographic reconstruction. Paleoceanography 27.

Teitler, L., Florindo, F., Warnke, D.A., Filippelli, G.M., Kupp, G., Taylor, B., 2015. Antarctic Ice Sheet response to a long warm interval across Marine Isotope Stage 31: A cross-latitudinal study of iceberg-rafted debris. Earth and planetary science letters 409, 109-119.

Thoma, M., Jenkins, A., Holland, D., Jacobs, S., 2008. Modeling Circumpolar Deep Water intrusions on the Amundsen Sea continental shelf. Geophysical Research Letters 35, L18602. https://doi.org/ 10.1029/2008GL034939.

Villa, G. and Wise, S.W., 1998. Quaternary Calcareous nannofossil from the Antarctic region. Terra Antarctica 5 (3), 479-484.

Villa, G., Lupi, C., Cobianchi, M., Florindo, F., Pekar, S.F., 2008. A Pleistocene warming event at $1 \mathrm{Ma}$ in Prydz Bay, East Antarctica: Evidence from ODP Site 1165. Palaeogeo. Palaeoclim., Palaeoeco. https://doi.org/10.1016/j.palaeo.2007.08.017.

Villa, G., Persico, D., Sherwood, W.W., Gadaleta, A., 2012. Calcareous nannofossil evidence for Marine Isotope Stage 31 (1 Ma) in Core AND-1B, ANDRILL 
700 McMurdo Ice Shelf Project (Antarctica). Global and Planetary Change. $701 \quad$ https://doi.org/10.1016/j.gloplacha.2009.12.003.

702 Winter, D., Sjunneskog, C., Scherer, R., Maffioli, P., Riesselman, C., 703 Harwood, D., 2010. Pliocene-Pleistocene diatom biostratigraphy of nearshore 704 Antarctica from the AND- 1B drillcore, McMurdo Sound. Global and Planetary $705 \quad$ Change. https://doi.org/10.1016/j.gloplacha.2010.04.004.

706 Yin, Q.Z. and Berger, A., 2012. Individual contribution of insolation and $\mathrm{CO}_{2}$ to 707 708 709 710 


\section{Supplementary Information for:}

\section{Southern Ocean temperature records and ice-sheet models demonstrate rapid Antarctic ice sheet retreat under low atmospheric $\mathrm{CO}_{2}$ during Marine Isotope Stage 31 .}

*Beltran Catherine ${ }^{1}$, Golledge Nicholas R. ${ }^{2,3}$, Ohneiser Christian ${ }^{4}$, Kowalewski Douglas E. ${ }^{5}$, Sicre Marie-Alexandrine ${ }^{6}$, Hageman Kimberly J. ${ }^{7}$, Smith Robert ${ }^{1}$, Wilson Gary S. ${ }^{1}$, Mainié François ${ }^{6}$.

Corresponding author: Catherine Beltran

Email: catherine.beltran@otago.ac.nz

1. Department of Marine Science, University of Otago, PO Box 56, Dunedin 9054, New Zealand

2. Antarctic Research Centre, Victoria University of Wellington, Wellington 6140, New Zealand

3. GNS Science, Avalon, Lower Hutt 5011, New Zealand

4. Department of Geology, University of Otago, PO Box 56, Dunedin 9054, New Zealand

5. Department of Earth, Environment, and Physics, Worcester State University, Worcester, Massachusetts 01602, USA

6. Sorbonne Universités (UPMC, Univ. Paris 06)-CNRS-IRD-MNHN, LOCEAN Laboratory, 4 Place Jussieu, F-75005 Paris, France.

7. Department of Chemistry, University of Otago, PO Box 56, Dunedin 9054, New Zealand 


\section{Supplementary Information}

Section 1: Sea surface temperature proxies............................. 3

1.1. Alkenone thermometry............................................... 3

1.2. Long chain Diol Index thermometry for IODP Site U1361 ................ 4

1.3. Alkenone Calibration.................................................... 4

Section 2: Ice sheet/shelves simulations.................................. 5

2.1. Global Climate Modelling........................................... 5

2.2. Regional Climate Modelling........................................ 6

2.3. Ice Sheet Modelling............................................... 7

References for Supplementary Information .............................. 11

741

742

743

744

745

746 
748 Climate simulations require unambiguous, continuous, and well-dated SST records to 749 determine changes in latitudinal heat transport. Despite the emergence of new and 750 well calibrated paleotemperature proxies based on diatom morphometry (e.g. Allen, 751 2014; Kloster et al., 2018; Shukla and Romero, 2018), the few available high latitude 752 Southern Ocean SST reconstructions for MIS31 were either derived from 1) proxies 753 based on calcareous nannofossil and planktonic foraminifera assemblage 754 compositions that tend to be less reliable at high latitudes where the species diversity 755 is low 2) diatom assemblages which composition reflect not only temperatures but 756 also environmental parameters such as sea ice, nutrients and light etc... or 3) 757 uncorrelated temperature proxies possibly reflecting temperatures of different water 758 masses and/or seasons, which adds significant uncertainties to climate reconstructions.

759 The lack of accurate and consistent SSTs for the Sub-Antarctic and Antarctic zones of 760 the Southern Ocean during MIS31 greatly restricts our ability to precisely quantify the 761 global latitudinal ocean heat transfer and subsequent sub-ice ocean heat flux, 762 impacting our ability to simulate the AIS response to ocean temperature changes. To 763 reconstruct the most continuous latitudinal record of the SSTs during the MIS31 764 super-interglacial along a transect from Sub-Antarctic to Antarctic water bodies in the 765 Atlantic sector of the Southern Ocean, we used two complementary organic 766 geochemical proxies for SSTs: the alkenone unsaturation ratio $\left(\mathrm{U}^{\mathrm{k}}{ }_{37}\right.$, Prahl et al., 767 1988) and the Long Chain Diol Index (LDI, Rampen et al., 2012).

$768 \quad$ 1.1. Alkenone thermometry

769 The $\mathrm{C}_{37}$ alkenone unsaturation index $\left(\mathrm{U}^{\mathrm{k}^{\prime}}{ }_{37}\right.$; Eq. 1) is a robust proxy for SST, 770 providing surface ocean temperature reconstructions with a precision of $+/-1.2{ }^{\circ} \mathrm{C}$ 771 (Sikes and Volkman, 1993; Muller et al., 1998; Conte et al., 2006). 


$$
\mathrm{U}^{\mathrm{k}}{ }^{\prime}{ }^{\prime}=\frac{\left[\mathrm{C}_{37: 2}\right]}{\left.\left[\mathrm{C}_{37: 2}\right]\right]+\left[\mathrm{C}_{37: 3}\right]} \quad \text { Eq. } 1
$$

774 Global core-top studies demonstrate that $\mathrm{U}^{\mathrm{k}}{ }_{37}$ correlates best with mean annual 775 temperatures at 0-10 $\mathrm{m}$ water depth range (Conte et al., 1993) and there is little 776 evidence that the SST signal is affected by other environmental parameters such as 777 productivity or salinity.

778 Previous studies (Sikes and Volkman, 1993; Conte et al., 2006;) showed that south of $77940^{\circ} \mathrm{S}$ in the Pacific and Atlantic sectors of the Southern Ocean, alkenone production is 780 limited to late spring-summer. As both ODP Sites 1090 and 1094 chosen in our study 781 were drilled south of the subtropical front, the $\mathrm{U}^{\mathrm{k}^{\prime}}{ }_{37}$-derived SST reconstructions are 782 likely to reflect the mixed-layer conditions during the warmest months of the year.

\subsection{Long chain Diol Index thermometry for IODP Site U1361}

784 The Long-chain diol index (LDI; Eq. 2) is defined as:

785

786

$$
\mathrm{LDI}=\frac{\left[\mathrm{C}_{30} 1,15-\text { diol }\right]}{\left[\mathrm{C}_{28} 1,13-\text { diol }\right]+\left[\mathrm{C}_{30} 1,13-\text { diol }\right]+\left[\mathrm{C}_{30} 1,15-\text { diol }\right]}
$$

Core top studies indicate that the LDI index is linearly correlated to SSTs $\left(+/-2^{\circ} \mathrm{C}\right)$ in a range of temperatures from $-3^{\circ} \mathrm{C}$ to $27^{\circ} \mathrm{C}$ (Eq. 3) with salinity and nutrient conditions having little to no influence (Rampen et al., 2002).

$$
\mathrm{LDI}=0.033 \times \mathrm{SST}+0.095
$$

Eq. 3

\subsection{Alkenone Calibration}

Most alkenone-derived SST reconstructions use the calibration of Prahl et al.(1988) based on the empirical linear relationship between $\mathrm{U}^{\mathrm{k}^{\prime}}{ }_{37}$ and SST obtained from laboratory cultures. However, several studies show that the $U^{k^{\prime}}{ }_{37}$ measured in particulate matter of surface waters disagree with this calibration (Prahl et al.,1988). These observations led to the development of alternate calibrations either global such 
798 (Muller et al., 1998; Sikes and Volkman, 1993).

799 To select the most accurate $\mathrm{U}^{\mathrm{k}^{\prime}}{ }_{37}$ calibration, we have extended the ODP Site 1094 800 sampling (Fig. S1) to cover the long term evolution of SSTs until today.

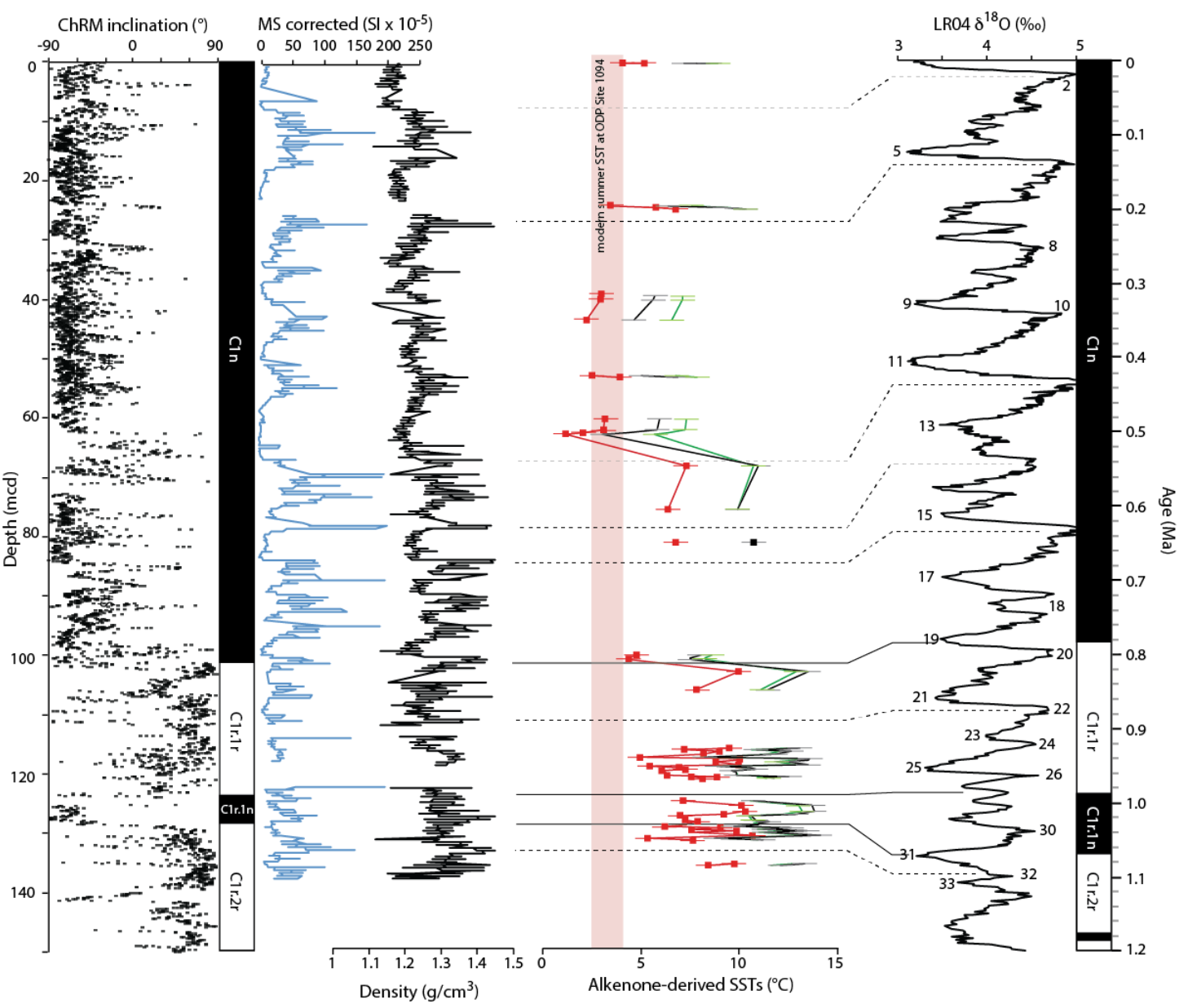

Fig. S1. Long term evolution of the alkenone-derived sea surface temperatures at ODP Site 1094 using three different calibrations: Prahl et al. (1988) in red; Sikes and Volkman (1993) in green; Conte et al. (2006) in black. Our additional low resolution dataset shows that the Prahl et al.(1988) calibration leads to SSTs that are similar to the modern ones at the same location.

When comparing the core top SSTs with the Levitus monthly modern SSTs it appears

808 that the Prahl et al. (1988) calibration leads to values that are consistent with the 809 modern February SSTs at the same location (Fig. S1). We have thus converted the 810 alkenone index into temperature using the Prahl et al. (1988) calibration.

811 Section 2: Ice sheet/shelves simulations 


\subsection{Global Climate Modelling.}

The relationship between air and ocean temperatures under different $\mathrm{CO}_{2}$ conditions evolves through time (Rugenstein et al., 2016), such that in Antarctica, short-term (< 100 year) sea-surface temperature anomalies are considerably less than the equilibrium state (Fig. S2 below). When attempting to infer an atmospheric warming from our oceanic proxy data, therefore, we conservatively assume that the ocean / atmosphere warming has achieved balance (taking c. 1000 years), and thus mean annual sea temperature anomalies are likely to be c. 2.5 times the inferred mean annual air temperature anomaly (SST to air ratio of 0.4 , Fig. S2).
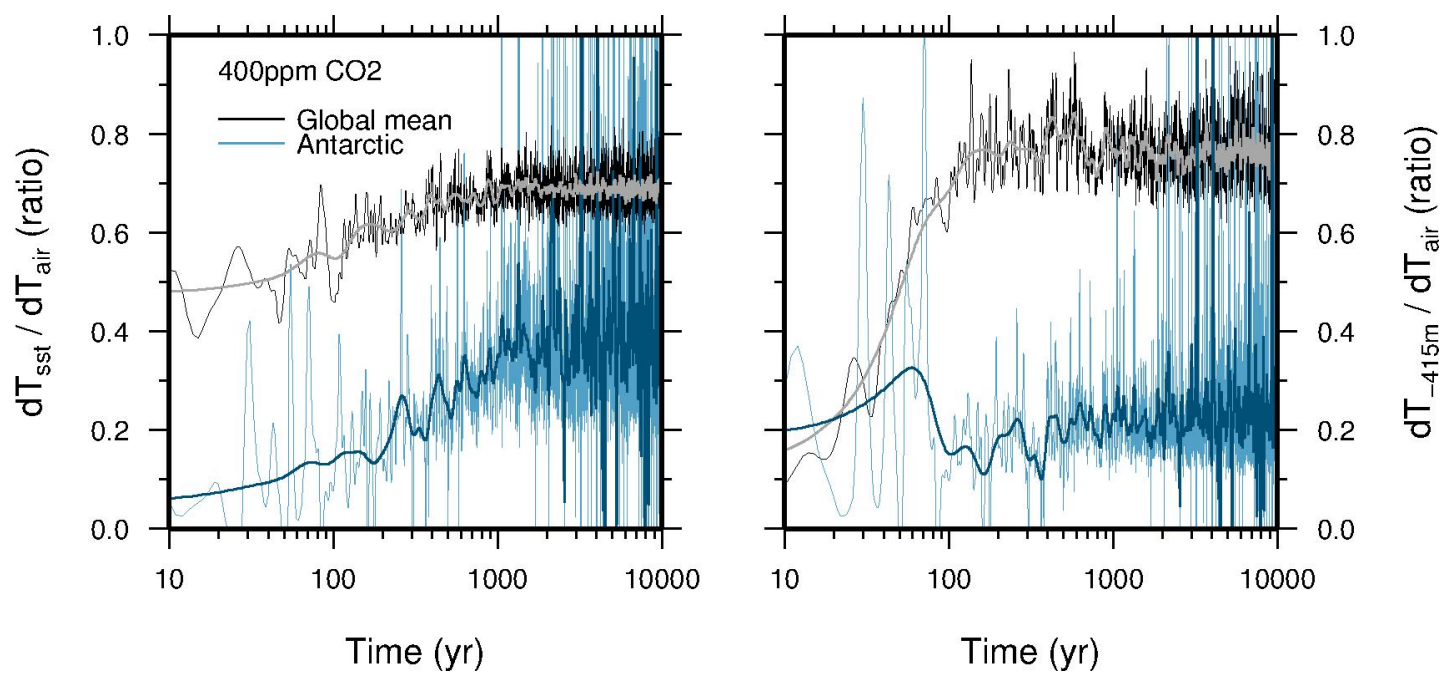

Fig. S2. Evolution of the relationship between mean annual surface air temperature anomaly and that of the sea surface (left) and ocean at $415 \mathrm{~m}$ depth (right) for Antarctica, compared to the global mean (Rugenstein et al., 2016). An equilibrium SST to air ratio of 0.4 implies a 2.5 times greater air temperature anomaly than that felt by the sea surface.

\subsection{Regional Climate Modelling}

Paleoclimate simulations were run using RegCM3_Polar. The regional climate model, RegCM3, was adapted to Antarctica (RegCM3_Polar) centered on the South Pole for Antarctic reconstructions. Boundary conditions for the regional model were taken from the library of existing GCM Pliocene simulations (GENESIS v. 3.0.; Pollard and DeConto, 2009). Simulations varied greenhouse gas, orbital, sea ice and SST 
835 and GCM. The boundary forcing from GENESIS GCM was interpolated horizontally 836 and vertically to the RegCM3_Polar grid and topography and was applied at 6-hour

837 intervals for both $40 \mathrm{~km}$ and $80 \mathrm{~km}$ horizontal resolution regional climate simulations.

838 Regional climate simulations were run using existing ice configuration and a MIS31

839 modeled ice sheet configuration imported from the Pollard and DeConto ice sheet /

840 shelf model output (Pollard and DeConto, 2009).

841
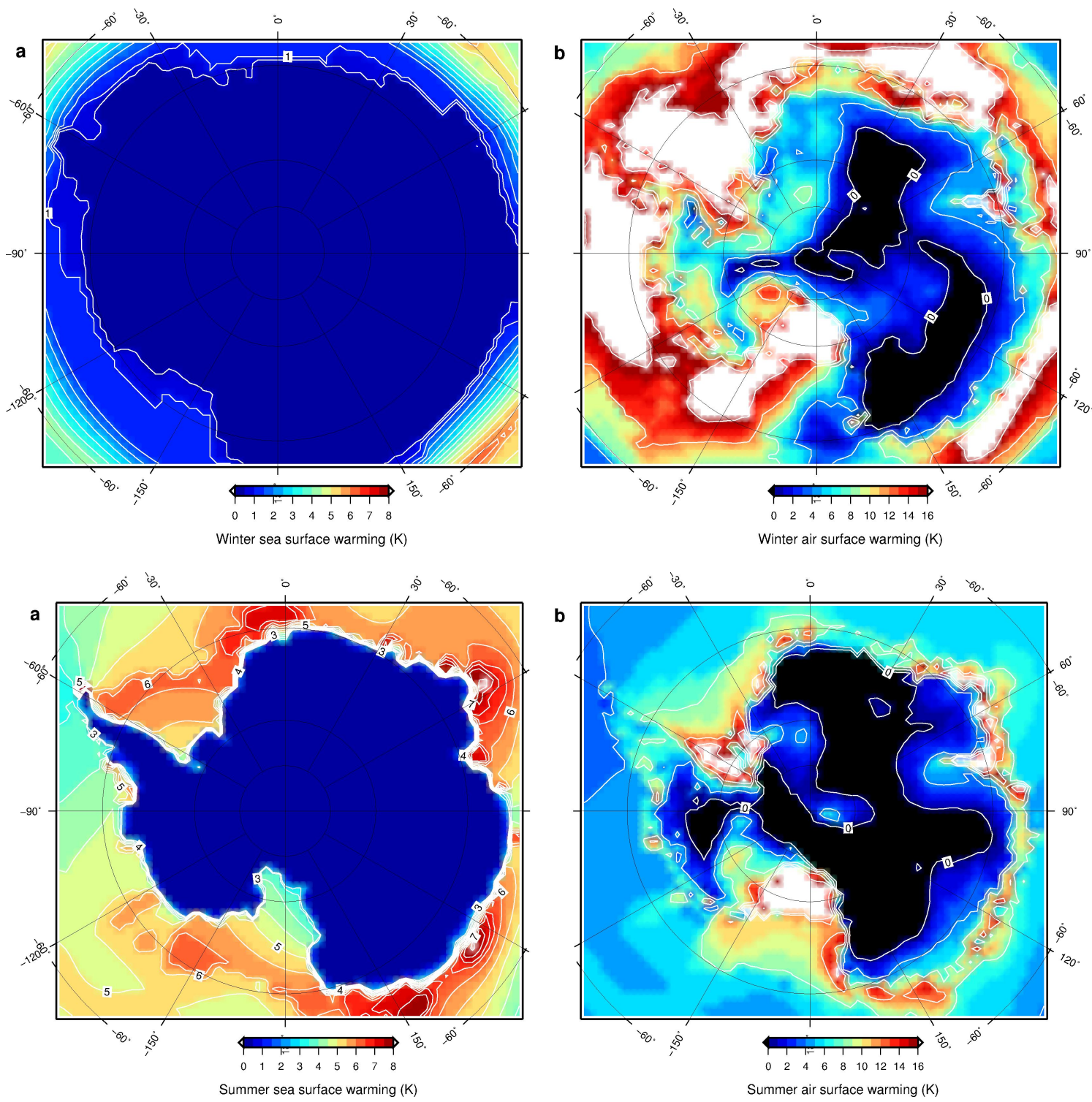
Fig. S3. Seasonal climatologies for Antarctica during MIS31, as simulated by the Regional Climate Model, as anomalies from present-day.

848 For our ice sheet experiments we use the climatologies from the RCM simulations 849 (Fig. S3) as anomalies to present-day air temperature and precipitation fields 850 (Lenaerts et al., 2012), in the same manner as employed previously (Golledge et al., 851 2017a). We use monthly climate fields in order to capture the high-latitude changes in 852 seasonality brought about by the different orbital configuration of MIS31, compared 853 to present. A positive-degree day model translates temperatures above freezing into 854 surface melt, of which a proportion $(60 \%)$ is retained in the snowpack through 855 percolation refreezing processes. This value is difficult to constrain precisely (Kuipers 856 Munneke et al., 2011) but here we use a constant value for both our control and our 857 perturbation experiments, thus differences in the results are not likely to arise from 858 errors in this parameterisation.

859 We use the Parallel Ice Sheet Model (PISM) version 0.6. Fast flow of grounded ice is 860 facilitated by the plastic failure of subglacial sediments that arises as a consequence of 861 an initially prescribed till friction angle, representing sediment strength, and its 862 saturation state, which evolves dynamically in concert with the thermal properties of 863 the basal layer of overlying ice. Thus where ice reaches sufficient thickness to allow 864 basal melting to occur, meltwater begins to weaken the substrate until driving stresses 865 exceed the evolving cohesiveness of the till. Failure of the substrate and the 866 concomitant acceleration of overlying ice obeys a pseudo-plastic law (Schoof, 2006;

867 Bueler and Brown, 2009), such that small increments of stress above the shear 868 strength of the substrate lead to an increasing velocity response that ultimately thins 869 the ice, reducing its driving stress and leading to deceleration of the ice. The cyclic 
behaviour of ice streams that occurs as a consequence of this mechanism is described

871 in more detail elsewhere (Van Pelt and Oerlemans, 20120. PISM employs a sub-grid

872 grounding line scheme (Feldmann et al., 2014) in which sub-ice shelf melt may be

873 interpolated across the grounded-floating ice junction, or not. The former approach

874 tends to accelerate ice sheet retreat in marine basins, whereas the latter produces a

875 slower response (Golledge et al., 2015). Equilibrium states tend to differ less between

876 the two approaches than do retreat rates, however. For completeness, we run duplicate

877 experiments both with, and without, the sub-ice shelf grounding line melt

878 interpolation scheme turned on. Once afloat, we impose two calving mechanisms -

879 one based on horizontal strain rates (Levermann et al., 2012), and another in which a

880 simple minimum thickness criterion (200m) must be satisfied.

881 With the model setup described above, we undertook a series of simulations to 882 explore the range of likely ice sheet responses to MIS31 climate states as simulated by 883 the RCM. We ran experiments for two climate scenarios, reflecting atmospheric $\mathrm{CO}_{2}$ 884 concentrations of 280 and $400 \mathrm{ppm}$, and for each of these ran duplicates with each of 885 the two grounding line parameterisations described above. We also ran a control 886 experiment in which a present-day climate field was maintained throughout. All 887 simulations were run for 10000 years and were initialised from a thermally and 888 dynamically stable configuration used previously (Golledge et al., 2015; Golledge et 889 al., 2017a; 2017b) which closely resembles the present-day ice sheet (Fig. S4 panel a).

890 RCM-derived climatologies were imposed at the beginning of each run and the ice 891 sheet was allowed to freely evolve to the new boundary conditions. Ice sheet 892 configurations after 5000 years for each of the experiments are shown in Figure S4. 

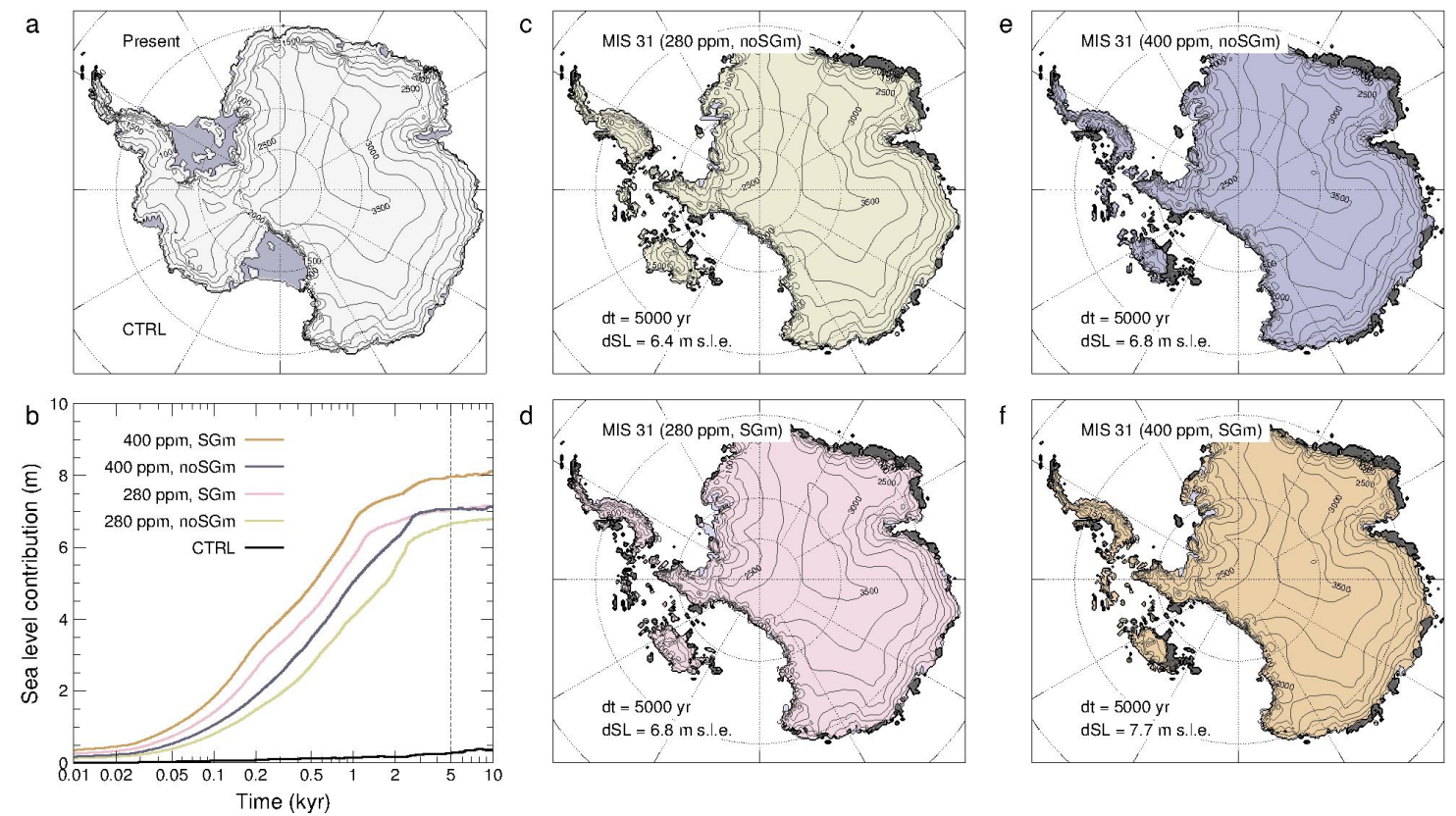

Fig. S4. Ice sheet geometry and contribution to global sea level after 5000 years of simulated MIS31 climates, using either 280 ppm or 400 ppm atmospheric $\mathrm{CO}_{2}$, and with one of two different groundingline schemes (noSGm, SGm; see text for details). Note the rapid response of the ice sheet under all scenarios (panel b), corresponding to the collapse timescale of WAIS.

900 Timeseries data illustrate that mass loss more-or-less stabilises after approximately

9015000 years in most cases. In all MIS31 experiments, WAIS is lost relatively rapidly

902 (first 1-2 millennia), with subsequent mass loss (from EAIS) taking place more 903 slowly. 


\section{References:}

Allen, C., 2014. Proxy development: A new facet of morphological diversity in the marine diatom Eucampia antarctica (Castracane) Mangin. Journal of Micropalaeontology 33, 131-142. https://doi.org/10.1144/jmpaleo2013-025.

Bueler, E. and Brown, J., 2009. Shallow shelf approximation as a "sliding law" in a thermomechanically coupled ice sheet model. Journal of Geophysical Research 114, F03008.

Conte, M.H. and Eglinton, G., 1993. Alkenone and alkenoate distributions within the euphotic zone of the eastern North Atlantic: correlation with production temperature. Deep-Sea Research 40, 1935-1961.

Conte, M.H., Sicre, M-A., Ruhlemann, C., Weber, J.C., Schulte, S., Schulz-Bull, D., Blanz, T., 2006. Global calibration of the alkenone unsaturation index $\mathrm{U}^{\mathrm{k}}{ }_{37}$ with surface water production temperature and a comparison of the coretop integrated production temperatures recorded by $\mathrm{U}^{\mathrm{k}^{\prime}}{ }_{37}$ with overlying sea surface temperatures. Geochemistry, Geophysics, Geosystems 72, 1-22.

Feldmann, J., Albrecht, T., Khroulev, C., Pattyn, F., Levermann, A., 2014. Resolution-dependent performance of grounding line motion in a shallow model compared to a full-Stokes model according to the MISMIP3d intercomparison. J. Glaciol. 60, 353-360.

Golledge, N.R., Kowalewski, D.E., Naish, T.R., Levy, R.H., Fogwill, C.J., Gasson, E.G.W., 2015. The multi-millenial Antarctic commitment to future sea-level rise. Nature 526. https://doi.org/10.1038/nature15706.

Golledge, N.R., Levy, R.H., McKay, R.M. Naish, T.R., 2017a. East Antarctic ice sheet most vulnerable to Weddell Sea warming. Geophys. Res. Lett. 44. https://doi.org/10.1002/2016GL072422.

Golledge, N.R., Thomas, Z.A., Levy, R.H., Gasson, E.G.W., Naish, T.R., McKay, R.M., Kowalewski, D.E., Fogwill, C.J., 2017b. Antarctic climate and ice sheet configuration during the early Pliocene interglacial at 4.23 Ma. Clim. Past 13, 117. https://doi.org/10.5194/cp-13-1-2017.

Kloster, M., Kauer, G., Esper, O., Fuchs, N., Beszteri, B., 2018. Morphometry of the diatom Fragilariopsis kerguelensis from Southern Ocean sediment: Highthroughput measurements show second morphotype occurring during glacials. Marine Micropal. 143, 70-79. https://doi.org/10.1016/j.marmicro.2018.07.002.

Kuipers Munneke, P., van den Broeke, M.R., Lenaerts, J.T.M., Flanner, M.G., Gardner, A.S., van de Berg, W.J., 2011. A new albedo parameterization for use in climate models over the Antarctic ice sheet. Journal of Geophysical Research 116, D05114. https://doi.org/10.1029/2010JD015113.

Lenaerts, J., van den Broeke, M., van de Berg, W., van Meijgaard, E., Munneke, P., 2012. A new high-resolution surface mass balance map of Antarctica (1979-2010) based on regional atmospheric climate modelling. Geophysical Research Letters 39, L04501.

Levermann, A., Albrecht, T., Winkelmann, R., Martin, M. A., Haseloff, M., Joughin, I., 2012. Kinematic first-order calving law implies potential for abrupt ice-shelf retreat. Cryosphere 6, 273-286. https://doi.org/10.5194/tc-6-273-2012.

Muller, P.J., Kirst, G., Ruhland, G., Von Storch, I., Rosell-Mele, A., 1998. Calibration of the alkenone paleotemperature index $\mathrm{U}^{\mathrm{k}}{ }_{37}$ based on core-tops from the eastern South Atlantic and the global ocean $\left(60^{\circ} \mathrm{N}-60^{\circ} \mathrm{S}\right)$. Geochimica et Cosmochimica Acta 62, 1757-1772.

Pollard, D. and DeConto, R.M., 2009. Modeling West Antarctic Ice Sheet growth and collapse through the last 5 million years. Nature 458, 329-332. 
Prahl, F.G., Muehlhausen, L.A., Zahnle, D.L., 1988. Further evaluation of long-chain alkenones as indicators of paleoceanographic conditions. Geochim. Cosmochim. Acta 52, 2303-2310.

Rampen, S.W., Willmott, V., Kim, J-H., E. Uliana, Mollenhauer, G., Schefuß, E., Sinninghe Damsté, J.S., Schouten, S., 2012. Long chain 1,13- and 1,15-diols as a potential proxy for palaeotemperature reconstruction. Geochimica et Cosmochimica Acta 84, 204-216.

Rugenstein, M.A.A., Sedláček, J., Knutti, R., 2016. Nonlinearities in patterns of longterm ocean warming. Geophysical Research Letters 43, 3380-3388. https://doi.org/10.1002/2016GL068041.

Schoof, C.A., 2006. Variational approach to ice stream flow. J. Fluid Mech., 556, 227-251.

Shukla, S.K. and Romero, O.E., 2018. Glacial valve size variation of the Southern Ocean diatom Fragilariopsis kerguelensis preserved in the Benguela Upwelling System, southeastern Atlantic. Palaeogeogr. Palaeoclimatol. Palaeoecol. 499, 112-122. https://doi.org/10.1016/j.palaeo.2018.03.023.

Sikes, E.L. and Volkman, J.K., 1993. Calibration of alkenone unsaturation ratios $\left(\mathrm{U}^{\mathrm{k}}{ }_{37}\right)$ for paleotemperature estimation in cold polar waters. Geochimistry et Cosmochimica Acta 57, 1883-1889.

Van Pelt, W.J.J. and Oerlemans, J., 2012. Numerical simulations of cyclic behaviour in the Parallel Ice Sheet Model (PISM). Journal of Glaciology 58, 347-360. 